\title{
Medical Police and the History of Public Health
}

\author{
PATRICK E CARROLL*
}

These hovels were in many instances not provided with the commonest conveniences of the rudest police; contiguous to every door might be observed the dung heap on which every kind of filth was accumulated ...

In 1942, Henry Sigerist questioned the idea that "the German way in public health was to enforce health through the police while the English way consisted in acting through education and persuasion". ${ }^{2}$ Contrasts of this kind have, however, remained commonplace throughout the twentieth century. ${ }^{3}$ In the 1950 s, George Rosen sought to reframe the history of public health in order to understand how it "reflected" its social and historical context. Despite critiques of Rosen's Whiggism, his work remains a source of current contrasts between public health and medical police. Rosen's analysis posited an inherent relationship between the idea of medical police and those of cameralism ${ }^{4}$ and mercantilism, particularly as developed in seventeenthand eighteenth-century Germany. ${ }^{5}$ Treating cameralism and medical police as "superstructural" forms subordinate to the political and economic relations of the ancien régime, he concluded that medical police was essentially a centralized form of continental and despotic government. It was incompatible with the forms of liberal

* Patrick Carroll, MA, PhD, Department of Sociology, One Shields Avenue, University of California, Davis CA 95616, USA. E-mail: pcarroll@ucdavis.edu.

The research was facilitated by a Faculty Research Grant from the University of California, Davis. For helpful suggestions and constructive criticism, I thank Chloe Burke, Harold Cook, Ruth Cronje, Margaret DeLacy, Steven Epstein, Christopher Hamlin, Joseph Manzione, Harry Marks, Russell C Maulitz, Christoph Mueller, Martin Pernick, Dorothy Porter, Sean Quinlan, Sally Sheard, Kevin Siena, and Annette Timm. I remain, of course, solely responsible for any errors.

\footnotetext{
${ }^{1}$ Benjamin Disraeli, Sybil, or the two nations, introduced by Patrick Cormack, London, The Folio Society, 1983 (1845), p. 70.

${ }^{2}$ Henry E Sigerist, Civilization and disease, Ithaca, Cornell University Press, 1943, p. 92.
}

\footnotetext{
${ }^{3}$ W F Bynum and Roy Porter (eds), Medical fringe \& medical orthodoxy 1750-1850, London, Croom Helm, 1987, pp. 187, 196 n. 33; Christopher Hamlin, Public health and social justice in the age of Chadwick: Britain 1800-1854, Cambridge University Press, 1998. German medical police history is sometimes represented in the idiom of "public health": Paul Weindling, 'Public health in Germany', in Dorothy Porter (ed.), The history of public health and the modern state, Amsterdam, Rodopi, 1994, pp. 119-131.

${ }^{4} \mathrm{~A}$ recent historical analysis of cameralism, though with little attention to medical police, is Isabel V Hull, Sexuality, state, and civil society in Germany, 1700-1815, Ithaca, Cornell University Press, 1996.

${ }^{5}$ George Rosen, 'Cameralism and the concept of medical police', Bull. Hist. Med., 1953, 27 : 21-42; idem, 'The fate of the concept of medical police 1780-1890', Centaurus, 1957, 5 (2): 97-113; idem, From medical police to social medicine: essays on the history of health care, New York, Science History Publications, 1974.
} 


\section{Patrick E Carroll}

democracy associated with the development of industrial capitalism, particularly in England. By the mid-nineteenth century it was a "sterile formula". ${ }^{6}$

It is difficult to gauge how direct the connection is, but subsequent Englishlanguage histories of medical police have been rare. ${ }^{7}$ A range of scholarship in the history of medicine, disease, and public health, and/or administration, government, police, and state formation, has provided discussions of medical police, ${ }^{8}$ yet its nature and history has received little sustained scrutiny in relation to the English case. While Foucault's work seemed to provide an opportunity to question the contrast

\footnotetext{
${ }^{6}$ Rosen, 'Fate of the concept', op. cit., note 5 above, p. 98. As he put it in his monumental history of public health, where he pushed its sterility a few decades further back in time: "the imposing concept of medical police was already hollow when peace and more settled conditions returned after Napoleon's downfall. Theory notwithstanding, the social purposes and ends of medical police were already outmoded and reactionary. During the early decades of the nineteenth century, this concept was an ideological superstructure set upon the crumbling foundations of absolutism and mercantilism. In short, to undertake to apply this concept to the health problems of the new industrial society was to offer a solution in terms of a remedy even then ready to be discarded". George Rosen, A history of public health, expanded ed., Baltimore, Johns Hopkins University Press, 1993 (1958), p. 142.

${ }^{7}$ Roy MacLeod's essay, 'The anatomy of state medicine: concept and application', in F N L Poynter (ed.), Medicine and science in the 1860s, London, Wellcome Institute of the History of Medicine, 1968, pp. 199-227, remains one of the few general treatments of medical police and "state medicine" in England. It is still a crucial reference for anyone interested in English medical police history. The English-language publication in 1976 of an abridged version of Johann Frank's System of complete medical police, ed. Erna Leskey, Baltimore, Johns Hopkins University Press, 1976 (1779-1825), did not stimulate much further research. But see Brenda M White, 'Medical police, politics and police: the fate of John Roberton', Med. Hist., 1983, 27: 407-22; Harold Cook, 'Policing the health of London: the College of Physicians and the early Stuart monarchy', Soc. Hist. Med., 1989, 2: 1-33; L J Jordanova, 'Policing public health in France 1780-1815', in Teizo Ogawa (ed.), Public health: proceedings of the 5th international symposium on the comparative history of medicine - east and west, Tokyo, Saikon, 1981, pp. 12-32.

${ }^{8}$ Dorothy Porter, Health, civilization and the state: a history of public health from ancient to
}

modern times, London, Routledge, 1999; Weindling, op. cit., note 3 above; Matthew Ramsey, 'Public health in France', in D Porter (ed.), op. cit., note 3 above, pp. 45-118; Marc Raeff, The well-ordered police state: social and institutional change through law in the Germanies and Russia, 1600-1800, New Haven, Yale University Press, 1983. See also, Gerhard Oestreich, Neostoicism and the early modern state, New York, Cambridge University Press, 1982; Theodore M Brown, 'J P Frank's “Medical Police" and its significance for medicalization in America', in Marten W de Vries, Robert L Berg, and Mack Lipkin, Jr (eds), The use and abuse of medicine, New York, Praeger, 1982, pp. 208-19; Richard Evans, Death in Hamburg: society and politics in the cholera years, 1830-1910, New York, Oxford University Press, 1987; Ute Frevert, 'The civilizing tendency of hygiene: working class women under medical control in imperial Germany', in John C Fout (ed.), German women in the nineteenth century, New York, Holmes and Meier, 1984, pp. 320-44; Donna Andrew, Philanthropy and police: London charity in the eighteenth century, Princeton University Press, 1989; Jan Goldstein, Console and classify, Cambridge University Press, 1987; E P Hennock, 'Vaccination policy against smallpox, 1835-1914: a comparison of England with Prussia and imperial Germany', Soc. Hist. Med., 1988, 11 (1): 49-71; Christopher Lawrence, 'Sanitary reformers and the medical profession in Victorian England', in Ogawa (ed.), op. cit., note 7 above, pp. 145-68; Catherine J Kudlick, Cholera in postrevolutionary Paris: a cultural history, Berkeley, University of California Press, 1996; David Arnold, Colonizing the body: state medicine and epidemic disease in nineteenth-century India, Berkeley, University of California Press, 1993. Of particular interest is Mary Lindemann, 'Producing policed man: poor relief, population policies and medical care in Hamburg, 1750-1806', unpublished $\mathrm{PhD}$ thesis, University of Cincinnati, 1980. 


\section{Medical Police and the History of Public Health}

between England and the rest of Europe, ${ }^{9}$ English "governmentality studies" have drawn upon historical studies of public health in order to lock in the contrast. ${ }^{10}$ For instance, by presenting medical police as an essentially German or continental phenomena inherently at odds with English political culture, Thomas Osborne dispatches it as irrelevant to English history. "Britain", he suggests, "was a country without a tradition of police". " Little effort is made to explain the differences between "public health", "state medicine", "medical jurisprudence" and "medical police". The categories are assumed instead to be discrete and self-evident, so that the possibility of England having a history of medical police seems as unlikely now as it was when Sigerist wrote some sixty years ago.

In this paper I take Sigerist's caution seriously, arguing that it is unhelpful to view the differences between medical police and public health in terms of "opposite models" of development. I present evidence suggesting that the relative absence of talk of medical police in England, and the eventual adoption of the idiom of public health across Europe, reveals more about the politics of the terminology used to

\footnotetext{
${ }^{9}$ Michel Foucault, 'The politics of health in the eighteenth century', in Colin Gordon (ed.), Power/knowledge: selected interviews and other writings 1972-1977, New York, Pantheon, 1980; idem, The history of sexuality, vol. 1: an introduction, 3 vols, New York, Vintage, 1980 (1976); idem, 'Omnes et singulatim: towards a criticism of political reason', in Lawrence D Kritzman (ed.), Michel Foucault: politics, philosophy, culture-interviews and other writings 1977-1984, New York, Routledge, 1988 (1979), pp. 57-85. Foucault's lecture outlines from the late 1970 s give a good indication of his work on police, which had not led to substantial research before his death in 1984: 'Society must be defended'; 'Security, territory, and population'; 'The birth of biopolitics'; 'On the government of the living', in Paul Rabinow (ed.), Ethics: subjectivity and truth, in the series The essential works of Foucault 1954-1984, vol. 1, New York, The New Press, 1997, pp. 51-86. See also the lectures on governmentality reprinted in Graham Burchell, C Gordon and P Miller (eds), The Foucault effect: studies in governmentality, University of Chicago Press, 1991, pp. 87-104. Foucault's radical chronological change of direction, from which he did not manage to return before his untimely death in 1984, is represented by vols 2 and 3 of The history of sexuality: The use of pleasure, 1990 (1984), and The care of the self, 1988 (1984).

${ }^{10} \mathrm{See}$, for instance, the introduction to medical police, and particularly the citations, in Dorothy Porter and Roy Porter (eds), Doctors, politics and society: historical essays, Amsterdam, Rodopi, 1993, pp. 3-5; Bynum and Porter (eds), op. cit., note 3 above; Hamlin, op. cit., note 3 above. One can generally expect to see "German-
}

speaking Europe" in the same sentence as "medical police", even when the latter is defined in a manner ("health regulation and preventative medicine") that makes it equally applicable to all western states. Roy Porter, The greatest benefit to mankind: a medical history of humanity, New York, W W Norton, 1997, p. 11. See also, Terence Ranger and Paul Slack (eds), Epidemics and ideas: essays on the historical perception of pestilence, Cambridge University Press, 1992, esp. Slack's introduction and John Pickstone's chapter, 'Fever epidemics and British "public health", 1780-1850'. Only Slack refers to Cook's crucial contribution on medical police in seventeenth-century England. See Cook, op. cit., note 7 above. Pickstone's piece is a crucial historiographic injunction, particularly in terms of his call to integrate the history of fever hospitals in Ireland and Scotland with the history of public health in England, and to view the history of public health through theories of fever. Of particular interest in this respect is the controversy sparked in Ireland by Dominic Corrigan's essay, On famine and fever as cause and effect in Ireland; with observations on hospital location, and the dispensation in outdoor relief of food and medicine, Dublin, Fannin, 1846; also, Anon., 'Review of Corrigan's "On famine and fever as cause and effect", Lond. Med. Gaz., or J. Pract. Med., 1846, 2: 385-7. See also, below, the discussion of the Irish "medical charities".

${ }^{11}$ Thomas Osborne, 'Security and vitality: drains, liberalism, and power in the nineteenth century', in Andrew Barry, Nikolas Rose, and Thomas Osborne (eds), Foucault and political reason: liberalism, neo-liberalism and rationalities of government, University of Chicago Press, 1996, pp. 99-121, p. 105. 


\section{Patrick E Carroll}

represent the enforcement of health than it does about actual changes in the way such enforcement developed. ${ }^{12}$ The rise to dominance of the idiom of public health did not, I suggest, clearly signal the discovery/construction of a new object or a new body of knowledge that made it possible for "public health" to break free of "police". The idiomatic shift was tactical in the political sense rather than epistemic in the cultural sense. The decline of mercantilism and the rise of political economy did not lead to a decline of police and a corresponding rise of persuasion. Rather than "public health" becoming a new scientific and government strategy that "reflected" a new political reality, a new idiom emerged that refracted the representation of medical police practice in a way that sought to make it palatable to those who viewed police as the antithesis of liberty.

While my argument is crucially conceptual, my method is historiographically empirical. Thus I analyse a range of sources that demonstrate the existence of a culture of medical policing (and police generally) in England. I document substantial similarities between the content of publications articulated in the language of "medical police", "state medicine", "medical jurisprudence", and those in the more familiar idiom of "public health". I provide broad evidence for doubting the view that modern public health culture has ever, in England or elsewhere, been "opposed" to police. My method is informed by Bruno Latour's suggestion that we focus less on professions and institutions (about which we know much) and more on networks of practice and culture. ${ }^{13}$ The result is not only an expansion in our understanding of the history of public health, but in our understanding of medical police, and indeed of police generally.

\section{Health, Safety, Security and Police}

It is useful to distinguish the idea of police from police as a practice. ${ }^{14}$ There emerges in Europe, from the seventeenth century at least, an idea of police centred around the exercise of government powers of investigation, regulation and prosecution in the service of "security". The idea exhibits a remarkable resilience over time and across Europe, despite differences in the way it was worked out in practice in the context of varying discourses of political liberty and the limits of government power. As Christopher Hamlin shows, the centralization of police in England was limited

\footnotetext{
${ }^{12}$ For examples of the analysis of the "politics of representation", see Seth Chaiklin and Jean Lave (eds), Understanding practice: perspectives on activity and context, New York, Cambridge University Press, 1993; Allen D Grimshaw (ed.), Conflict talk: sociolinguistic investigations of arguments in conversations, Cambridge University Press, 1990; Michael Shapiro, The politics of representation, Madison, University of Wisconsin Press, 1988.

${ }^{13}$ Bruno Latour, 'The costly ghastly kitchen', in Andrew Cunningham and Perry Williams (eds), The laboratory revolution in medicine, Cambridge University Press, 1992, pp. 295-303.
}

My approach attempts to bring the insights of science studies to bear on the history of medicine and public health, particularly its "methodological relativism" (not to be confused with ontological or moral relativism).

Methodological relativism facilitates moving beyond what Dorothy Porter has described as "heroic" versus "anti-heroic" Whig historiographies. 'Introduction' to D Porter (ed.), op. cit., note 3 above, pp. 1-44.

${ }^{14}$ Though I present this definition of police at the outset of this paper, it is not a preconceived definition by which I sorted the empirical material It emerged rather from the research itself. 


\section{Medical Police and the History of Public Health}

by a strong tradition of local government. The role of police in the realization of public health (particularly with respect to the differential targeting of particular groups or classes) was bound up in struggles over individual liberty and social justice. ${ }^{15}$ Yet even in the context of these national differences, the development of police in England proceeded in a similar way to other European countries. It was configured in practices of inspection and surveillance, information and intelligence gathering, and direct intervention (to the point of deadly force) in private, familial and commercial matters.

Medical police did not normally include the deployment of deadly force-an important difference and one that needs emphasizing-but was, none the less, configured within the general ideas and practices of police. From the beginning of the police idea, security was tied to "health and safety" through the concept of "population". In this context, the ideas and practices of investigation, regulation and prosecution, and inspection, information gathering and intervention, were central to medical police practice. From this perspective, one can distinguish the objects of medical policing in terms of seven broad categories: (1) the police of the "community"-women and workers often singled out for special attention (and prostitutes and the poor even more so); (2) the police of "nuisances", a broad term focused upon conditions and activities believed to compromise the health and safety of the "public", expressed in the nineteenth century in the language of "sanitary reform", ${ }^{16}$ and thereby united with the police of the community; (3) the police of the physical environment, practised through the science of "sanitary engineering" and united via sanitarianism with the police of groups and nuisances; (4) the police of that which is ingested by bodies, especially in terms of the adulteration and wholesomeness of food, drugs and water; (5) the police of dangerous materials (for example explosives and poisons) and activities directly affecting safety, such as traffic and construction sites; (6) the police of occupational hazards; and (7) the police of medical practitioners and suppliers such as doctors, apothecaries and "quacks" (and in the eighteenth century, witches). Because these ideas and practices were embodied in law, medical police tended to overlap with "medical jurisprudence" and connected with "forensics", "police chemistry", ${ }^{17}$ and the employment of expert witnesses in court. Finally, medical police was designedly a "science", though one regularly expressed in a discourse of moral imperative.

To the extent that these activities can be correlated in a consistent way with the ideas and practices of "public health", one can suggest that public health embodied elements of medical police. And similarly, to the degree that these activities can be identified in English public health, it can be suggested that the English case is not as different from the rest of Europe as is sometimes thought. The purpose of this paper, then, is to stimulate further debate by questioning two ideas that seem to circumvent that discussion: first, the idea that the differences between medical police and public health rise to the level of an opposition; and second, the idea that the difference between England and the rest of Europe rises to the level of exceptionalism.

${ }^{15}$ Hamlin, op. cit., note 3 above.

${ }^{16}$ Lawrence, op. cit., note 8 above.
${ }^{17}$ R A Wakefield, 'Police chemistry', $S c i$ Context, 2000, 13 (2): 231-67. 


\section{Patrick E Carroll}

Rather than offer an alternative to current histories, my aim is to balance an understanding of the differences with an understanding of similarities, to contextualize the specificities of England and its localities within the wider history of the UK and Europe, and to specify the place of medical police within the history of public health generally. The paper is intended as a contribution to other works that evidence crucial differences and discontinuities in the history of medical police and public health across Europe, not least of which, in the case of England, was the political culture of suspicion and even hostility towards centralized and therefore "designing" government. ${ }^{18}$

\section{Early Meanings of Police}

The oldest English definition of police equated it with policy, meaning organized government or civil administration. "Polyce" could designate both scheme and practice, denoting a general political strategy and a specific tactical deployment. In the mid-seventeenth century, the modern spelling referred less to an organized body of men than it did to policy (an idea or scheme rather than a practice or organization).$^{20}$ It was used and spelt in this way as late as 1773 in the laws of Scotland. ${ }^{21}$ Indeed, the discourse of police was evident early in Scottish law, precisely in terms of its meaning as civilizing government, and from the late eighteenth century Scotland saw a series of "Police and Improvement" Acts.

The discourse of "improvement" was central to the English "civilizing mission" in both Ireland and Scotland in the seventeenth and eighteenth centuries, and evoked

\footnotetext{
${ }^{18}$ Hamlin, op. cit., note 3 above, pp. 193, 336, $340,304,269$.

${ }^{19}$ It was used in this sense from the sixteenth century. See, Surrey (c. 1540) in Miles Prance, The additional narrative, containing his vindication of the machinations of the Papal and Jesuitical party, London, 1679, p. 36: "Steryng [steering] them with all perswasions, ingynes, and Polyce to dedd Images and Counterfeit Relics." It is important to note here, as Foucault has pointed out, that "words and things" had not been wrenched apart until the mid to late seventeenth century. Thus just as "polyce" could mean both police and policy, depending on the context, so too could "ingyn" mean both engine and ingenuity. See also, Andrew Boorde, The fyrst boke of the introduction to knowledge, ed. F J Furnivall, London, published for the Early English Text Society by Kegan Paul, Trench, Trubner, 1870 (1547), pp. 137; 186: "My scyences and other polyces dyd kepe me in fauour"; "I werke by polyse, subtylte, and craught." On the separation of sign and signified, idea and thing,
}

see Michel Foucault, The order of things: an archaeology of the human sciences, New York, Vintage, 1973, esp. chs 3-5; and in relation to the history of natural history: "Natural history finds its locus in the gap that is now opened up between things and words", pp. 129-30. The importance of the break identified by Foucault has been duly confirmed by a more conventional history: William B Ashworth, Jr, 'Natural history and the emblematic world view', in David C Lindberg and Robert S Westman (eds), Reappraisals of the scientific revolution, Cambridge University Press, 1990, pp. 302-32.

${ }^{20}$ Jordanova was referring to the eighteenth century, but the point holds even stronger for the seventeenth. Jordanova, op. cit., note 7 above, p. 14. See, for instance, Richard Brome, The northern lasse, 1632: "The plot smells of your Ladyship's police", republished in Dramatic works, London, Pearson, 1873.

${ }^{21}$ John Erskine, An institute of the law of Scotland adopted from 1768, 2 vols, Edinburgh, John Bell, 1773, vol. 1, p. 152. 


\section{Medical Police and the History of Public Health}

reclamation and cultivation in the broadest sense of the terms. ${ }^{22} \mathrm{~A}$ more tenuous connection also existed with the notion of "polished", police expressing subtlety and refinement. Indeed the meaning of "civilization" linked the Latin politus, from which "polish" and "politeness" derived, with the Greek polis, from which police, politics, and policy derived. "Reclamation" was a policy that evoked moral meanings of winning back from wildness, barbarity, immorality and "waste" condition. Thus as early as 1549, the anonymous author of the Complaynt of Scotland remarked with satisfaction that "Nature provokit them [the Scots] to begyn sum litil police, for sum of them began to plant treis, sum to dant [hunt and tame] beystis, [and] sum gadthrid the frutis". ${ }^{23}$ It was in this respect that one of the early meanings of police was the improvement of an estate, building, or town, and that a "policy" could designate the enclosed, planted, and cultivated area of land around a country seat. Failure to tame "wild nature", to bring it under civilized government, was seen as proof of a lack of moral culture. ${ }^{24}$

The first officially designated police body in Britain was the Scottish Commissioners of Police, established by Queen Anne in 1714 for the general internal administration of the country. This appears to be the earliest official use of the word in the British Isles based on the Greek root polis, meaning the regulation, discipline and government of land and people, the enforcement of law and the securing of public order through civil administration. As an official construction of meaning, this conceptualization served the distinction drawn with "policy" later in the eighteenth century. The latter was confined to external relations of government, understood today as "foreign policy". "Police" was restricted to the arts and sciences of government as they pertained to the internal affairs and security of the state, a distinction adopted by Johnson in his 1755 dictionary, and relied upon two decades later by Adam Smith in his lectures on government. ${ }^{25}$

As in other parts of Europe, the link between police and health was made early in Britain. Smith demarcated police, one of four departments of "jurisprudence", in a manner that connected security with the government of commerce and health. "Cleanliness and security", defined as "the proper method of carrying dirt from the streets, and the execution of justice, in so far as it regards regulations for preventing crimes or the method of keeping a city guard", were excluded from his lectures on

\footnotetext{
${ }^{22}$ On improvement and the civilizing mission in Ireland, see Toby Barnard, 'The Hartlib circle and the cult and culture of improvement in Ireland', in $M$ Greengrass, $M$ Leslie, $T$ Raylor (eds), Samuel Hartlib and universal reformation: studies in intellectual communication, Cambridge University Press, 1994, pp. 281-97; idem, 'Gardening, diet and "improvement" in later seventeenth-century Ireland', J. Garden Hist., 1990, 10 (1): 71-85; idem, 'Improving clergymen, 1660-1760', in A Ford, J McGuire, K Milne (eds), As by law established: the Church of Ireland since the Reformation, Dublin, Lilliput Press, 1995 , pp. 136-65. On the opposition between "wild nature" and "civil culture", with their correlates of barbarity and civility respectively,
}

see Joep Leerssen, 'Wildness, wilderness, and Ireland: medieval and early-modern patterns in the demarcation of civility', J. Hist. Ideas, 1995, 56: $25-39$.

${ }^{23}$ Anon., Complaynt of Scotland, ed. James A H Murray, 3rd ed., Oxford, Early English Text Society, 1872 (1549), p. 145.

${ }^{24}$ Patrick Carroll, 'Engineering Ireland: the material constitution of the technoscientific state', $\mathrm{PhD}$ thesis, University of California, San Diego, 1999.

${ }^{25}$ Samuel Johnson, A dictionary of the English language, London, $\mathrm{W}$ Strachan, $\mathrm{J}$ and $\mathrm{F}$ Rivington, 1773 (1755). Adam Smith, Lectures on justice, police, revenue and arms, ed. Edwin Cannan, Oxford, Clarendon Press, 1896, p. 154. 
the grounds that they were "too mean [common] to be considered in a general discourse of this kind". ${ }^{26}$ Instead Smith focused on what he termed "commercial police", the objective of which, he argued, should be the attainment of "cheapness and plenty".

Smith's approach to police, directed at commerce rather than health, expresses the concerns of the emerging field of liberal political economy which he sought to shape. It also indicates the very broad scope of police in the eighteenth century, even in England. Arguing from the principle that "dependency" is the greatest corrupting force upon "mankind", Smith posited the "establishment of commerce and manufactures" as "the best police for preventing crimes". ${ }^{27}$ "Free trade" economics was not opposed to police, it was a particular policy of police. ${ }^{28}$ Thus Smith elevated economic security to a very high level in his calculations of general police and order, maintaining a continuity between "mercantilism" and "political economy", between politics as a science and the police of economic activity and relations. In an important sense early "political science" was police science, and "political economy" was the police of trade, agriculture and manufacture (Smith's lectures in the 1750s comprehended political economy under the heading of "police and revenue"). ${ }^{29}$

Steven Kaplan's analysis of the "political economy of bread" in eighteenth-century France demonstrates how widely "security" and police were defined in late-eighteenthcentury Europe. Grain cultivation, bread production and price levels were policed and regulated, police being the means through which "government sought to assure the subsistence of the people". ${ }^{30}$ Reporting on the agricultural police in France, Arthur Young did not condemn it, but argued that every country was in need of "a good police of corn; a police that shall, by securing a high price to the farmer, encourage his culture enough to secure the people at the same time from famine". ${ }^{31}$ As Ludmilla Jordanova suggested in relation to the French case, one should not "associate the eighteenth century form of police either with a uniform, homogeneous state apparatus or with a unified professional structure for those jobs which involved policing". 32

A recent study of the police of London "before the Bobbies" provides a similar historiographic injunction in the English case. Elaine Reynolds questions the idea that Robert Peel's new police marked a radical departure from earlier forms. ${ }^{33}$ The

\footnotetext{
${ }^{26}$ Smith, Lectures, ibid., p. 154.

${ }^{27}$ Ibid., p. 155.

${ }^{28}$ The issue, therefore, is best understood less in terms of intervention versus no intervention, and more in terms of what kind of intervention.

${ }^{29}$ Police could extend to all areas of internal government practice. See William Greig, Strictures of road police, containing views of the present systems, by which roads are made and repaired, together with sketches of its progress in Great Britain and Ireland, from the earliest to the present time, Dublin, Archer, Cumming, Milliken, Dugdale, Keene, Hodges \& McArthur, and Larkin, 1819. Greig, a road engineer in the employ of the postmaster general, and advocate of a system of county engineers for building and
}

maintaining roads, chose the title "Road Police" because the "care of roads forms so important a branch, of the highly interesting and widely extended subject of political economy, or the domestic policy of nations", p. xii.

${ }^{30}$ Steven L Kaplan, Bread, politics and political economy in the reign of Louis $X V, 2$ vols, The Hague, Martinus Nijoff, 1976, vol. 1, p. 11.

${ }^{31}$ Arthur Young, Travels in France during the years 1787, 1788, and 1789, ed. with intro. by Jeffry Kaplow, Garden City, Doubleday, 1969, p. 141.

\footnotetext{
${ }^{32}$ Jordanova, op. cit., note 7 above, p. 14.

${ }^{33}$ Elaine A Reynolds, Before the Bobbies: the night watch and police reform in metropolitan London, 1720-1830, London, Macmillan, 1998.
} 


\section{Medical Police and the History of Public Health}

acceptance of the new system occurred rather quickly because of the "degree of continuity" between the parish watch and the Metropolitan force. ${ }^{34}$ She shows how "complex policing and police reform were", and how earlier local English initiatives provided much of the theory and method that informed the design of more centralized forces. The development of police in England is not well captured by the idea of top-down governors imposing restrictions upon resistant localities. Police reform throughout the eighteenth and nineteenth centuries was "many-faceted", originating in "many locations" and "thrashed out at many levels". ${ }^{35}$ The emphasis on "policing as prevention", so central to the concept of medical police, was well established in England through a system of "parish government" that was "a pivotal arena not only for the implementation of national policies but for initiatives that strengthened the government as a whole". ${ }^{36}$ As well as detecting crimes and preserving the peace, the duties of the early police included enforcing liquor laws, regulating traffic, assisting Poor Law officers, fire prevention, improving the paving, lighting and cleanliness of streets, and the general detection and removal of "nuisances" and other "annoyances".

The link between charity and police is an important one in English political culture during this period. As Donna Andrew recently put it, eighteenth-century English philanthropists summed up the social function of charity under the term "police". ${ }^{37}$ The deployment of charity as an instrument of police is particularly evident in colonial Ireland. In Ireland there was always a tension in political discourse between the extremes of "racism", which posited the Irish as a nation without hope of reclamation from their supposed moral degeneracy, and colonial nationalism, which promoted the power of charity and police to civilize the native Irish. ${ }^{38}$ For instance, the Philanthropic Society, founded by Anglo-Irish reformers in Dublin in 1788, emphasized the "truth and importance of those views of charity and police" which established a link between private benevolent activity and the maintenance of moral and political order. ${ }^{39}$ In Scotland and Ireland, the discourse of barbarism and civilization served to infuse necessity and urgency into questions of police and security. The first recognizably modern "police force" in the British Isles (some would say the world) began its life in London, but was rejected by the powerful merchants there and deployed instead in Dublin in $1786 .^{40}$ The new force, in keeping with the broad sense of police, had a wide range of responsibilities that included the enforcement of commercial and traffic laws, and the removal of various nuisances. In the early nineteenth century, a national force was created which grew in number throughout the century. It became successively more disciplined, sophisticated, and sober, expanding its scope of activity and becoming a "sanitary police", a "fire police", and an "intelligence" police (through, among other things, collection of the decennial and agricultural censuses).

\footnotetext{
${ }^{34}$ Ibid., p. 162.

${ }^{35}$ Ibid., pp. 162-3.

${ }^{36}$ Ibid., p. 3.

${ }^{37}$ Andrew, op. cit., note 8 above, p. 6.

${ }^{38}$ George Berkeley, $A$ word to the wise: or, an exhortation to the Roman Catholic clergy of Ireland, Dublin, George Faulkner, 1752.
} 


\section{Patrick E Carroll}

\section{Early Critiques of Police}

As early as the late eighteenth century, critiques of police focused upon the way the principle and practice was used not to secure civilization and public good, but to defend tradition and suppress legitimate grievance. Political protest became increasingly combative in the context of the commercialization of agriculture (with the subsequent loss of rural privileges) and the industrialization of manufacture (the "Yorkshire slavery"). The smashing of machines and killing of cattle were classified as "outrages" deserving the harshest punishment. Even traditionally accepted labourers' takings from private land were sometimes met with little mercy. In this context police was easily perceived as an engine of state violence.

Though the scope of police concerned "every aspect of daily life, moral and material", ${ }^{41}$ the abuse of police power in defence of both established and revolutionary order meant that it quickly became viewed as the "political pretext and the administrative mechanism which authorities used to diminish and enslave men" ${ }^{42}$ The growing association of police with unbridled state power generated sustained suspicion of it as both idea and practice, and indeed undermined the legitimacy of government itself. In France, the actions of the revolutionary forces under the authority of the "Committee of Public Safety" did not help matters. "Public Safety", through the cold efficiency of the guillotine, became directly associated with bloody political terror. In a wider sense, police was increasingly associated in the discourses of political economy with unwelcome government interference in production and trade, and indeed private property rights generally. ${ }^{43}$ As Hamlin shows, public health also became a political battlefield. The medical élite opposed manufacturers over factory regulations. Solutions to health were cast by some (particularly Chadwick) in terms of technical fixes (sanitarianism), while others sought to make it an issue of "social justice". ${ }^{44}$ The hostility of commercial interests to public health derived precisely from the recognition by employers that such initiatives compromised the idea of a domain of private property absolutely free unto itself. Public health and safety provided a rationale and an opening for police to investigate, regulate and prosecute within that domain. The idea of the policing of economic activity in the name of health and safety was generally anathema to the sensibilities of commercial property, and the experience of inspection, information gathering and intervention did little to soften that opposition as the nineteenth century progressed.

It was in the context of the French Revolution and the growing intensity of political conflict in England that a discourse of police emerged in which the focus upon "crime" crowded out everything else, especially health. In Britain, one of the most influential contributors to this newly focused police discourse was Patrick Colquhoun, whose most famous work proceeded as though there was no such thing

\footnotetext{
${ }^{41}$ Kaplan, op. cit., note 30 above, p. 12.

${ }^{42}$ Ibid., p. 13. Kaplan notes that a writer in the Encyclopédie méthodique at the end of the old regime suggested that police had already lost its old meaning and become "hardly respectable". For critics, police came to mean the "regime of
}

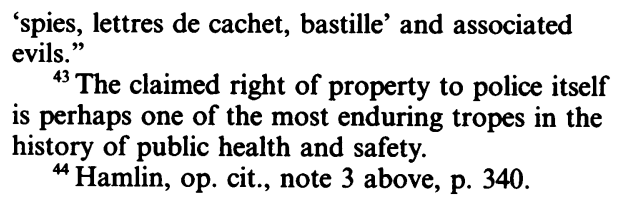
is perhaps one of the most enduring tropes in the history of public health and safety.

${ }^{44}$ Hamlin, op. cit., note 3 above, p. 340. 


\section{Medical Police and the History of Public Health}

as "medical police", in Britain or anywhere else..$^{45}$ Though on occasion making reference to adulteration, Colquhoun did so only in terms of the policing of fraud. Despite his rhetoric of morality and improvement, he said practically nothing about the health and safety of the people. His was a conservative conceptualization of security centred upon protecting property and moralizing the poor. Without any of the reference to the security of the "population" so characteristic of continental police, his work marked a reorientation of the police idea strictly around the agenda of preserving Britain's bourgeois order. Appearing a decade after the French Revolution, his discourse of police exhibited all the anxiety generated by the shocking spectacle of the Leviathan literally losing its head. Colquhoun drew a radically circumscribed relationship between "commerce and police", one that said nothing about the police of trade and manufacture with respect to health and safety. Instead the focus was almost entirely on protecting "moving property" (i.e. capital goods) from fraud, theft and other "deprevations". ${ }^{46}$

Despite Colquhoun's narrowing of the idea of police around felonious crimes, ${ }^{47}$ the broader idea of medical police did not disappear. While the association of police with the curtailment of liberty led to an idiomatic shift away from talk of medical police, the tight connection already drawn between safety, health and security continued to be central to all forms of police, whether criminal, medical, fire preventative, or moral. Even Colquhoun's river police, designed at the behest of commercial interests for the protection of their cargo, would later have the prevention of river pollution and other "nuisances" added to their duties.

\footnotetext{
${ }^{45}$ Patrick Colquhoun, $A$ treatise on the police of the metropolis; containing a detail of the various crimes and misdemeanors by which public and private property and security are, at present, injured and endangered; and suggesting remedies for their prevention, New Jersey, 1806, Patterson Smith, 1969, reprint of the 7th ed. (1st ed. 1795). Whereas Hanway, cf. below, declared "life" to be the object of police, Colquhoun made life secondary to property: "Under the present circumstances of insecurity, with respect to property, and even life itself". Preface.

${ }^{46}$ Idem, $A$ treatise on the commerce and police of the river Thames; containing an historical view of the trade of the port of London; the depredations committed on all property imported and exported there; the remedies hitherto applied; and the means of future prevention, by [a] complete system of river-police; with an account of the functions of the various magistrates and others exercising or claiming jurisdiction on the river; and of the penal statutes against maritime offences of every description, London, J Mawman, 1800.

${ }^{47}$ Colquhoun's narrow conceptualization of police has had far-reaching effects on how the history of police has subsequently been viewed. Indeed, the vast majority of current histories of police similarly have nothing to say about fire
}

police, sanitary police, medical police, police chemistry, and forensics, and only on occasion make brief reference to public health. See, for instance, Stanley $\mathrm{H}$ Palmer, Police and protest in England and Ireland 1780-1850, Cambridge University Press, 1988; Clive Emsley, The English police: a political and social history, New York, Addison Wesley Longman, 1991; Carolyn Steedman, Policing the Victorian community: the formation of English provincial police forces, 1856-80, London, Routledge \& Kegan Paul, 1984; Stephan Petrow, Policing morals: the metropolitan police and the Home Office, 1870-1914, Oxford, Clarendon Press, 1994. Part of the problem seems to stem from the fact that the only alternative to the "conflict" view of police as essentially an expression of state repression, is the equally untenable view that police was a pragmatic and essentially benevolent response to pressing social needs. See also the earlier histories: W L Melville Lee, $A$ history of police in England, Montclair, NJ, Patterson Smith, 1971 (1901); T A Critchley, A history of police in England and Wales 900-1966, London, Constable, 1967. For an account that emphasizes the centrality of information gathering and surveillance, see Carroll-Burke, op. cit., note 40 above. 


\section{Patrick E Carroll}

\section{The Idea of Medical Police}

There is no doubt that the great early works on medical police are continental in origin. Along with the work of Franz Anton Mai, Wolfgang Thomas Rau, and Johann von Justi, Johann Frank's monumental System of complete medical police marks the high point of the literature on government and health that went specifically under the name of medical police. ${ }^{48}$ Quoting Joseph von Sonnenfels, one of the earliest police scientists, Frank explained how the "internal security of the State is the aim of the general science of police". ${ }^{49}$ Sonnenfels, in Grundsätze der Polizey, Handlung und Finanz (Principles of the police, commercial and financial) (1765), provided a chapter 'On the security of the person' which dealt with many of the issues subsequently comprehended under medical police. ${ }^{50}$ Frank defined medical police, "like all police", as an "art of defense, a model of protection of people and their animal helpers". ${ }^{11}$ Like Sonnenfels and Rau, he situated medical police in relation to the wider science of government (Polizeiwissenchaft). Police encompassed government regulation of all entities within the territorial state, including the land, the bodies of the people, trade, factories, morals, entertainments, buildings, roads, and so on. "Life" became the object of police, "the indispensable, the useful, and the superfluous" ${ }^{52}$ Thus the population of a state, constituted as such through political arithmetic and policy/police, was located at the heart of a nexus of ideas and practices that defined the "modern art of government, or state rationality: viz., to develop those elements constitutive of individuals' lives in such a way that their development also fosters that of the strength of the state". ${ }^{53}$

Frank was a tireless advocate of this new art of government, introducing his opus on medical police through a discussion of the "value of a person and the advantages of the population". ${ }^{54}$ The idea that a large and healthy population was the basis of a powerful state was, of course, a central premise of mercantilism and cameralism, and was promoted in Ireland and England by William Petty as early as the late seventeenth century. ${ }^{55}$ At issue was the necessity of a policy and police with regard

\footnotetext{
${ }^{48}$ Johann Frank, System einer vollständigen medicinischen Polizey, Mannheim, C F Schwan, 1780-1788. Frank conceived of this work in 1766, and it appeared between 1779 and 1825 , the last volumes posthumously. The sixth volume consisted of two parts and three supplementary volumes. Dorothy Porter notes, however, that Frank's ideas had a long genealogy going back to the mid-seventeenth century, some of which were institutionalized in Sweden from the mideighteenth century. D Porter, op. cit., note 8 above. On Sweden, see Karin Johannisson, 'The people's health: public health polices in Sweden', in D Porter (ed.), op. cit., note 3 above, pp. $165-82$.

${ }^{49}$ Frank, op. cit., note 7 above, p. xvi.

${ }^{50}$ Joseph von Sonnenfels, Grundsätze der Polizey, Handlung und Finanz, Vienna, 1765. Discussed in Frank, op. cit., note 7 above, p. xv.

${ }^{51}$ Frank, op. cit., note 7 above, p. 12.
}

\footnotetext{
${ }^{52}$ Foucault, 'Omnes et singulatim', op. cit., note 9 above, p. 73 .

${ }^{53}$ Ibid., p. 82.

${ }^{54}$ Frank, op. cit., note 7 above, p. ix.

${ }^{55}$ Petty used the term "political medicine", a phrase which even into the nineteenth century had intimate connections with the prescriptions of medical police, to refer to some of the interventions government could adopt to achieve a greater and healthier population. In a letter to Southwell, 17 Dec. 1672, Petty described his political arithmetic and political anatomy as the foundation for the "political medicine" of Ireland, quoted in Edmond Fitzmaurice, The life of Sir William Petty, London, John Murray, 1895 , p. 158. See also William Petty, 'An essay for the emprovement [sic] of London', in The Petty papers, ed. Marquis of Lansdowne, 2 vols, London, Constable, 1927, vol. 1, pp. 33-7;

William Petty, Several essays in political
} 


\section{Medical Police and the History of Public Health}

(in Petty's words) to "hands" as well as "lands", a principle that for many was reinforced rather than overthrown by Malthusian doctrines in the nineteenth century. ${ }^{56}$ Indeed, the rapid development of censuses in the nineteenth century shows how population was increasingly constructed as a central object around which government acted. Thus Frank outlined a plan of government action for the security and increase of the population "from womb to tomb", as Rosen perceptively put it.

As on the continent, England's indigenous culture of police in the eighteenth century embraced the health of subjects. William Blackstone documented some of the laws against "nusance" [sic] and offences against the "public health" and "public police" elaborated over the previous two centuries. ${ }^{57}$ A nuisance was an "annoyance" that "worketh hurt, inconvenience, or damage". He described both public and private nuisances, where the former was an annoyance to all the king's subjects and the latter things that caused hurt or damage to an individual's property ${ }^{58}$ His discussion of nuisances is important because the idea became central to public health law and medical police practice in England and Ireland in the nineteenth century. ${ }^{59}$ As James Black put it in 1844, "nuisance" was a "legal term" which described various sources of "contamination" of the air, water, or environment, whether from chemical processes or manufactures, or from any other "annoyance" ${ }^{60}$ The term was still used in the comprehensive nineteenth-century public health legislation passed for both England and Ireland in the 1870s, though its meaning was by then refined to apply only in the case of proven danger to health. In nineteenth-century Ireland, Charles Cameron used the same kinds of examples as Blackstone, noting that the meaning of the term included "anything which causes injury or annoyance". But he qualified this by observing that in general "magistrates who have cases brought

arithmetick, London, Robert Clavel, 1699; John Gordon Smith, The principles of forensic medicine, systematically arranged and applied to British practice, London, Underwood, 1828; Anon., 'Dr Maunsell on political medicine', Dublin Univ. Mag., May 1839, 13: 551-65. Neither Frank nor Petty suggested that population could be increased without limit, though both believed that significant increases were not only possible but desirable. As Frank put it: "I repeat, therefore, there is no point in making so much fuss about population institutions, which basically are nothing so long as there is no realization of the great advantage realized if the people who are already here are preserved and made happy! ... In my opinion it would be ridiculous to try to fill a pond before the dams are secured; and to populate a country without protecting and preserving the inhabitants by prudent institutions is tantamount to trying to store water in a sieve." Frank, op. cit., note 7 above, p. 202.

${ }^{56}$ An article in the conservative Dublin

University Magazine, published in the immediate wake of the Great Famine, "utterly reject(ed) the doctrine of over-population", arguing that it was "mainly by human labour, judiciously directed, that wealth is produced; and that the more effective labour there is in a country, the greater will be the amount of its wealth." Anon., 'A glance at Irish statistics', Dublin Univ. Mag., Feb. 1855, p. 243.

${ }^{57}$ William Blackstone, Commentaries on the laws of England, 4 vols, Oxford, Clarendon Press, 1768, vol. 3, pp. 216-22, vol. 4, pp. 161-75.

58 "So that the nusances [sic] which affect a man's dwelling may be reduced to these three: 1 . Overhanging it, which is also a species of trespass ... 2. Stopping antient lights: and 3. Corrupting the air with noisom smells: for light and air are two indispensible requisites to every dwelling." Blackstone, Commentaries, vol. 3, p. 217.

"Antient lights" were windows which had "subsisted ... time out of mind."

${ }^{59}$ For instance: Nuisances Removal Act, 18 \& 19 Vict. c. 121, 1855. Nuisances Removal and Diseases Prevention (amendment) Act, 23 \& 24 Vict. c. 77, 1860. Nuisances Removal Act, 26 \& 27 Vict. c. $117,1863$.

${ }^{60}$ James Black, 'Lectures on public hygiene and medical police', Prov. Med. Surg. J., 1844, pt 19: 275-80; pt 22: 327-32; pt 24: 359-64; pt 26: 391-6; pt 36: 551-7; quotes pt 22, p. 327. 


\section{Patrick E Carroll}

under the provisions of the sanitary Acts only convict when it is proved that the nuisance complained of is injurious to health" ${ }^{61}$

Blackstone argued, in 1768, that offences against the public health and the "public police or oeconomy" were of the "highest importance" to the commonwealth. He explained that the police of health was performed in many English counties by "special magistrates or curators". ${ }^{62}$ A person residing in an "infected house" and found "wandering" could be flogged as a vagabond even if s/he was uninfected. If found to be infected, s/he was guilty of felony. ${ }^{63}$ Laws dating back to Henry III provided for the policing of provisions, particularly the sale of "corrupted wine, contagious or unwholesome flesh, or flesh that is bought of a Jew". All these, including that inspired by prejudice, were offences which "may properly be said to respect the public health". Blackstone partly distinguished "public police and oeconomy" from public health, itemizing the domain of the former in terms, for instance, of polygamy, "wandering impostors", idleness, dangerous "luxuries" and gambling. He also included "common" or public nuisances under police, defining them as "offences against the public order and oeconomical regimen of the state; being either the doing of a thing to the annoyance of all the king's subjects, or the neglecting to do a thing which the common good requires". ${ }^{64}$ Public nuisances included obstructions of highways and rivers, offensive trades and manufactures, the keeping of hogs in cities or market towns, disorderly inns, and "cottages" erected on "waste lands". The manufacture, trade and use of fireworks were prohibited because they were nuisances to public safety. Thus Blackstone defined "public police and oeconomy" quite widely:

By the public police and oeconomy I mean the due regulation and domestic order of the kingdom: whereby the individuals of the state, like members of a well-governed family, are bound to conform their general behaviour to the rules of propriety, good neighbourhood, and good manners; and to be decent, industrious, and inoffensive in their respective stations. ${ }^{65}$

Perhaps the most detailed plea for further widening the scope of police in eighteenthcentury England is Hanway's Defects of police, the cause of immorality (1775) ${ }^{66}$ Writing seven years after the Commentaries, Hanway addressed himself to the

\footnotetext{
61 "Thus, a Dublin police magistrate refused to order the abatement of a nuisance caused by the erection of a row of privies opposite a terrace of dwelling-houses, on the ground that though such an act was improper, yet it did not constitute a nuisance injurious to health." Charles Cameron, A manual of hygiene, public and private, and compendium of sanitary laws, Dublin, Hodges, Foster, 1874, p. 20.

${ }^{62}$ Blackstone, op. cit., note 57 above, vol. 4, p. 161 .

${ }^{63}$ The quarantine laws, confirmed and amended by $29 \mathrm{Geo}$. II. c. 8 , provided for forty days' confinement and the employment of "watchmen" for enforcement. The watchmen were subject to the same penalties as the infected for failing in their duties. The legislation,
}

according to Blackstone, put the law in "a much more regular and effectual order than formerly". Ibid., vol. 4, p. 162.

${ }^{64}$ Ibid., vol. 4, p. 167

${ }^{65}$ Ibid., vol. 4, p. 162.

${ }^{66}$ Jonas Hanway, The defects of police, the cause of immorality, and the continual robberies committed, particularly in and about the metropolis: with various proposals for preventing hanging and transportation: likewise for the establishment of several plans of police on a permanent basis, with respect to common beggars; the regulation of paupers; the peaceful security of subjects; and the moral and political conduct of the people: observations on the Rev Mr Hetherington's charity; and the most probable means of relieving the blind, London, J Dodsley, 1775. 


\section{Medical Police and the History of Public Health}

contemporary condition and its future relief. He defined his audience by reference to clergy, magistrates, overseers of the poor, and in particular the governors of charities, and of institutions such as hospitals, bridewells, and workhouses. Hanway distinguished English police in terms of its "fairness" in comparison to "some nations whom we affect to despise", and explained that "whether it respects the bodies or souls, of our fellow-creatures, charity is the condition required of us". ${ }^{67}$

The Irish "medical charities" are a particularly revealing example of the relationship between charity and police in English political culture. ${ }^{68}$ Consisting of a range of hospitals, infirmaries, asylums, and dispensaries, they were always dependent upon considerable government funding, and were accordingly subject to government oversight and regulation. Recognized as one of the most advanced health systems in mid-nineteenth-century Europe ${ }^{69}$ the medical charities can be understood in Hanway's terms as institutions of medical police. Viewing them in this way solves the apparent puzzle of why the dispensaries, through the Medical Charities Act of 1851, were placed under the jurisdiction of the Poor Law Guardians, and why the Act constituted the guardians as a medical police institution in a broad "environmental" sense of the term, such that they were required to employ "medical inspectors" and a "medical commissioner" charged with the enforcement of public health laws. When the Local Government Board (meaning central government of local government) was created in the 1870 s, the members of the new board were none other than the Poor Law Commissioners, but now with an even broader scope of police power. Thus the Irish medical charities are an exemplary case of charity and police constituting a single strategy for health, order and security. One might question what this had to do with England, but it should be remembered that these were crucially English designs, and that English reformers always kept abreast of government innovations in Ireland. ${ }^{70}$ This was especially true in the mid-Victorian period, when the congresses of the National Association for the Promotion of Social Science provided a forum for discussion and the exchange of information for the entire kingdom. ${ }^{71}$ Thus Ronald Cassell has demonstrated that the Irish system of the 1850s and 1860s provided the template for the English reforms of the 1870s and 1880 s. $^{72}$

\footnotetext{
${ }^{67}$ Ibid., pp. ii-iii.

${ }^{68}$ Ronald D Cassell, Medical charities, medical politics: the Irish dispensary system and the poor law, 1836-1872, Rochester, NY, Boydell Press, 1997.

${ }^{69}$ Oliver MacDonagh, 'Ideas and institutions, 1830-45', in W E Vaughan (ed.), A new history of Ireland, Oxford, Clarendon, 1989, vol. 5, pp. 193-217. See also Cassell above, for a qualification of this claim. Speaking of the "primal laws of public order and public health", Henry Rumsey lauded the Irish health system, and particularly the dispensary system, as "probably the best in Europe". He was happy to report that it had been adopted by the president of the London Poor Law board "as the model for his new organization of medical relief". Henry
}

Rumsey, On state medicine in Great Britain and Ireland, London, William Ridgway, 1867, p. 5.

${ }^{70}$ The innovations contained in the Irish convict system in the 1850 s and 1860 s caused a furore over the question of why the same techniques were not being adopted in England. A Royal Commission of investigation was formed in the 1870s, but it was the late 1890 s before the Irish system was adopted in England. CarrollBurke, op. cit., note 40 above, esp. ch. 5.

${ }^{71}$ Ibid., ch. 5. Also, Transactions of the National Association for the Promotion of Social Science, London, 1857-1880.

${ }^{72}$ Cassell, op. cit., note 68 above, pp. 161-2. Consistent with the changed times, Cassell dropped the term "state medicine" which was in the title of the work when it appeared as his PhD 
Hanway denied that "private actions" stood in opposition to government police, explaining that charity, which sprang from the "impulse of the heart", demanded "regulations as will encourage the industrious; chastise the idle; instruct the ignorant; and punish the profligate". While he insisted that government must rest upon the "foundation of religion", he none the less argued that "national security and happiness" could be realized only by "the detail of government, or call it police". ${ }^{33}$ Many philanthropists, like Hanway, promoted the deployment of the "coercive power" of government police ${ }^{74}$ as an instrument of "charity". Using the language of "national security", Hanway practically equated government with police, expressing exactly the meaning the term held on the continent. Despite mobilizing all the English tropes which set the country in opposition to the continent, such as liberty, fairness, charity, philanthropy, and private action, Hanway was unambiguous in his view that "without energy in government to enforce, no well-digested police can be established; and that it will never be obtained, unless it is paid for" ${ }^{75}$ The scope of Hanway's design for police is as wide as any found on the continent, covering all manner of institutions, the living conditions of the poor, the material structure of cities, education, cleanliness and health, the economy, and the virtues of industriousness and morality. "Life" itself, he proclaimed in concert with the greatest police theorists of continental Europe, is "confessedly the great object of police" ${ }^{76}$ Hanway demonstrates the extent to which neither police in general, nor medical police in particular, were alien to English political culture, even in the eighteenth century.

thesis: 'Medical Charities Act of 1851 and the growth of state medicine in mid-Victorian Ireland', University of North Carolina, 1977. Medical police legislation extended beyond the medical charities. See, for instance, Regulations for the Prevention of Contagious Diseases in Ireland Act, 39 Geo. III c. 41, 1819. Diseases Prevention Act, 18 \& 19 Vict. c. 116, 1855. Nuisances Removal Act, 18 \& 19 Vict. c. 121, 1855. Nuisances Removal and Diseases Prevention (amendment) Act, 23 \& 24 Vict. c. 77, 1860. Nuisances Removal Act, 26 \& 27 Vict. c. 117, 1863. Public Health Act, 11 \& 12 Vict. c. 63, 1848. Sanitary Act, 29 \& 30 Vict. c. $90,1866$. Sanitary Loans Act, 32 \& 33 Vict. c. 100, 1866. Sanitary Act, 31 \& 32 Vict. c. 115, 1868. Sanitary Act, 33 \& 34 Vict. c. 53, 1870. Public Health (Ireland) Act, 37 \& 38 Vict. c. 93, 1874. Local Government Act, 1858, amended 1861, 24 \& 25 Vict. c. 61,1861 . Local Government Act, 34 \& 35 Vict. c. 109, 1871. Local Government Acts, 35 \& 36 Vict. c. 69,1858 , amended 1861; 34 \& 35 Vict. c. 109,1871 , amended 1872 . Common Lodging Houses Acts, 14 \& 15 Vict. c. 28,$1851 ; 16$ \& 17 Vict. c. 41,$1853 ; 23$ \& 24 Vict. c. 26, 1860.

Labouring Classes Lodging Houses and Dwellings (Ireland) Act, 29 \& 30 Vict. c. 44, 1866. Artizans and Labourers Dwellings Act, 31 \& 32 Vict. c. 130, 1868. Labouring Classes Dwellings Act, 30 Vict. c. 28, 1866. Public Parks (Ireland) Act, 32 \& 33 Vict. c. 28, 1869. Gas and
Water Works Facilities Act, 33 \& 34 Vict. c. 70, 1870. Burial Grounds (Ireland) Act, 19 \& 20 Vict. c. 98,1856 . Burial Act, 33 \& 34 Vict. c. $98,1871$. Towns Improvement Acts, 17 \& 18 Vict. c. 103, 1854 , which incorporated sections from the Towns Improvement Clauses Act, 1847; Commissioners Clauses Act, 1847; Lands Clauses Consolidation Act, 1845. Lighting, Cleansing, and Watching of Towns Act, 9 Geo. IV c. 82. Sewer and Sewage Utilization Acts, 28 \& 29 Vict. c. 75, 1865; Amended, 29 \& 30 Vict. c. 90, 1866; Petroleum Acts, 25 \& 26 Vict. c. 66, 1862; 35 \& 36 Vict. c. 56, 1872. Sale of Poisons Act, 33 \& 34 Vict. c. 26, 1870. Bakehouse Regulation Act, 26 \& 27 Vict. c. 44, 1866. Adulteration of Food, Drugs and Medicines, 9 Geo. II c. 10, 1735; Adulteration of Food Act, 23 \& 24 Vict. c. 84, 1860; Adulteration of Food, Drink and Drugs (amendments) $35 \& 36$ Vict. c. 74, 1872.

Licensing Act, 1872. There is also a series of Building Acts with clauses relevant to health and safety, some of which were incorporated in the Local Government Act, 1858, such as the size of rooms, the thickness of walls, the height of ceilings, the provision of yards, and the safety of roofs and chimneys.

${ }^{73}$ Hanway, op. cit., note 66 above, pp. ii-iii.

${ }^{74}$ Ibid., p. 283.

${ }^{75}$ Ibid., p. v. Italics in original.

${ }^{76}$ Ibid., p. 255. 


\section{Medical Police and the History of Public Health}

That such a cogent conceptualization of police and its relation to health could be articulated in eighteenth-century England is not surprising given that the idea of investigation, regulation and prosecution in the interests of health was conceived as early as the seventeenth century. ${ }^{77}$ Harold Cook documents the measures taken by the Stuart monarchy to "preserve the health of the body politic", particularly the schemes for regulating and governing the practice of medicine in London, the use of royal charters to create hierarchies amongst the competing medical corporations and societies, and the institution of new plans for regulating public health and hygiene. ${ }^{78}$ Cook demonstrates, through an analysis of the appeals made to parliament by those practitioners disadvantaged, that medical policing caused difficulties for the claimed absolute authority of the monarch, contributing to the forces that led to the Civil War. Cook's article is an effective challenge to the "unexamined consensus that the idea of medical police did not exist in England until the later eighteenth century, and that the ideas could not be acted upon until the later nineteenth century". 79

If the extent to which ideas translated into practice was doubtful for the nineteenth century, it was doubly so for the seventeenth. None the less, the early English schemes are important because they complicate the proposition that medical police was essentially un-English. Though a board of health with medical policing powers was not created in seventeenth-century England (the Civil War put an end to the scheme), the Privy Council expressed the logic of such a board in a report in the 1630s. The report concluded that

the prevencion of all which inconveniences and many more which tyme and observacion may discover doth especially yea wholy consist in providing a sufficient aucthoritie both within the libertiyes and without either by waye of Commission or office of health, or other meanes which your Honour shall thincke fitt; to provide officers particularly to looke out and discover these misdemeanours, and that they being trulye discovered, ther maye bee in the commission or office of health or other meanes sufficient authoritie and power to punish such as shalbe found delinquents. ${ }^{80}$

Though Cook's article is mostly focused on the police of medical professionals and apothecaries, it also shows that moves were made to establish authorities charged with broad responsibilities for preserving the public health. The work of Paul Slack on the impact of the plague in Tudor and Stuart England confirms this, even if the measures taken were often ad hoc responses to particular crises. Though conducted largely in the idiom of public health, Slack's analysis shows how, in the second half of the sixteenth century, the Privy Council inched its way towards creating a "large corps of officials" who would visit homes with a view to inspection and the

\footnotetext{
${ }^{77}$ Cook, op. cit., note 7 above.

${ }^{78}$ The College of Physicians' charter, for instance, delegated police powers to the College as early as the sixteenth century. The College was able to impose, in 1618, an official list of drugs to which the apothecaries were confined. In the late sixteenth and early seventeenth centuries, the halting policy regarding plague and public health
}

\author{
was given coherency by the Privy Council, and \\ statutory authority by James I. Regulations were \\ created in relation to epidemic plague, the \\ regulation of public meetings and slaughter \\ houses, the sale and provision of food, and the \\ regulation of traffic, among other things. Ibid. \\ ${ }^{79}$ Ibid., p. 4. \\ ${ }^{80}$ Quoted in ibid., pp. 24-5.
}




\section{Patrick E Carroll}

enforcement of plague law, particularly in terms of household segregation of the sick. ${ }^{81}$ From small and tentative steps initiated by central government, police interventions to prevent the spread of plague "gradually became commonplace and were imposed on the nation". ${ }^{82}$ These early moves towards policing the sick involved new interventions into the community as a whole, provoking the kind of controversy that became the mark of similar efforts throughout the eighteenth and nineteenth centuries.

The targeting and segregation of the infected initiated a characteristic feature of subsequent medical policing when directed at the community. In the eighteenth century entire groups were singled out for especially energetic measures, particularly (as is well known) the working classes and the poor. After the poor, perhaps the most consistently targeted group were prostitutes. Indeed, it is remarkable in this respect how concerns about sexually transmitted diseases were met by similar police strategies despite the fact that those concerns might be expressed in considerably different ideological contexts. Thus John Fielding, writing in a mid-eighteenthcentury discourse of enlightenment rationality and Christian humanitarianism, posited brothels (alongside gaming houses) "to be as material an Object of Police as any whatever". ${ }^{83}$ Like Hanway, and indeed John Howard, Fielding articulated a concept of police that linked private benevolence spurred by religious feeling with "rational" government and police design. Police, in this context, was intimately concerned with "prevention", "preservation" and "reformation". ${ }^{4}$

While one of the earliest British uses of the idiom of medical police occurred in Scotland, it was framed very much in terms of the English discourse of reform found in Hanway, Fielding and Howard. Andrew Duncan, professor of medicine at Edinburgh, lectured on medical police throughout the $1790 \mathrm{~s} .{ }^{85} \mathrm{He}$ published his Heads of lectures on medical jurisprudence as early as 1795 , and secured the first British chair of medical police and medical jurisprudence in 1807. Duncan argued that charity and philanthropy were necessary elements of effective police design. Patriotism served as the link between private philanthropic action and the need to protect and sustain the community as a national imperative. ${ }^{86}$ Duncan was similarly concerned with institutional mechanisms of medical police, such as the construction and management of special hospitals, dispensaries, workhouses and prisons. ${ }^{87}$ While Hanway was more of a police-man than a medicine-man, and Duncan more of a medicine-man than a police-man, taken together they illustrate the meeting of the two in eighteenth-century Britain, particularly in terms of the institutional and

\footnotetext{
${ }^{81}$ Paul Slack, The impact of plague in Tudor and Stuart England, London, Routledge \& Kegan Paul, 1985, pp. 207-26. The first plague regulations were promulgated as early as 1518 .

${ }^{82}$ Ibid., 226.

${ }^{83} \mathrm{John}$ Fielding, A plan of a preservatory and reformatory for the benefit of deserted girls, and penitent prostitutes, London, R Francklin, 1758, p. 2.

${ }^{84} \mathrm{John}$ Fielding, An account of the origin and effects of a police set on foot by His Grace the
}

\footnotetext{
Duke of Newcastle in the year 1753, upon a plan presented to His Grace by the late Henry Fielding, esq., London, A Millar, 1758. John Howard, The state of the prisons in England and Wales, London, William Eyres, 1784.

${ }^{85}$ Andrew Duncan, Heads of lectures on medical jurisprudence, Edinburgh, Adam Neill, 1795, published in 1801 as, Heads of lectures on medical jurisprudence and medical police.

${ }^{86}$ White, op. cit, note 7 above, p. 408.

${ }^{87}$ Ibid., p. 409.
} 


\section{Medical Police and the History of Public Health}

carceral dimension, which in nineteenth-century Ireland became one of the most elaborate English designs in police. ${ }^{88}$

In the first half of the nineteenth century, the idiom of medical police looked as if it might take greater hold in England, publications appearing with all the scope of their continental counterparts (though the term itself was already being supplanted by the new German favourite, "state medicine", and a host of others discussed below). John Roberton's Medical police: or the causes of disease, with the means of prevention, dealt with the "natural" and "artificial" causes of disease, and the types of disease associated with these causes. ${ }^{89}$ Under natural causes he covered the soil, climate, and situation (or place), and under artificial the construction of houses, occupations, "modes of living", and manners. Roberton's book, appearing postMalthus, is less optimistic regarding the possibility of safely increasing the population, but none the less proceeds on the basis of the principle that the "wealth of all nations arises from their quantity of productive labour" ${ }^{90}$ In this context he argued for medical police on the grounds that it was the best policy for reducing the proportion of the "inactive population".

Like Frank, Roberton designed a plan of government action on the principle that the "detection and removal of the causes of disease is in reality the true essence of medical police", a definition which just as readily captured the contemporary "essence" of public health. ${ }^{91}$ His plan called for the establishment of a "council of health", which would be responsible for appointing "inspectors" who would ensure that the measures for the prevention of disease were adhered to. The inspectors would see to it that soil found to "emit effluvia" be remedied, that "vitiated climate" be purified, and that the size of houses and apartments "be properly regulated", especially in terms of the location of doors, windows, and chimneys, the materials used in construction, and the modes of access for air through lanes, yards, and courts. All occupations where health was likely to be injured were to be "strictly attended to" by the police, and the "modes of living, particularly among the lower orders of society, to be in some measure examined, and regulated with that spirit of moderation which would soon put to silence the complaints of those who fell immediately under such scrutiny". ${ }^{92}$ According to Roberton, interference with "private property and domestic arrangements" was crucial, and it meant that a plan of medical police could not succeed without the authority of the legislature. Everything for which Chadwick would later become famous was presented by Roberton as medical police, perhaps with the exception of moderation in its execution, an idea not readily associated with the great engineer of health.

\footnotetext{
${ }^{88}$ Patrick Carroll, 'Science, power, bodies: the mobilization of nature as state formation', $J$. Hist. Sociol., 1996, 9 (2): 139-67. Carroll, op. cit., note 24 above.

${ }^{89}$ John Roberton, Medical police: or the causes of disease, with the means of prevention: and rules for diet, regimen, \&c. adapted particularly to the cities of London and Edinburgh, and, generally, to all large towns, 2 vols, London, J J Stockdale, 1812. The first edition bore the title $A$ treatise on medical police.
}

\footnotetext{
${ }^{90}$ Ibid., vol. 1, p. xlviii.

${ }^{91} \mathrm{He}$ explored police in relation to drainage, ventilation, food-handling, waste disposal, occupational hazards, diet, and eating utensils. He wrote subsections on the "police of soil", occupations, manners, etc., "police for the construction of houses", "police for climate", and so on. Ibid., vol. 2 , p. 351 .

${ }^{92}$ Ibid., vol. 2, pp. 355-7.
} 
Roberton's reference to "complaints" indicates that the forms of inspection, regulation, information gathering, intervention, and enforcement implied by medical police immediately evoked resistance. But such suspicion was neither unique to England nor specific to the nineteenth century. Frank noted as early as 1783 that "Medical Police is charged with too much curtailment of civic freedom and with aiding legislative despotic power" ${ }^{93}$ In relation to the policing of popular entertainments, he was acutely aware of the need for police to be dispatched with good judgement and respect for citizens. The notion that the police could "lord it over" the citizens had the result that the public, instead of feeling grateful for the "care" police provided, expressed the "greatest aversion to everything that is called police, and considers as nothing all the good that the police provides against the tyranny of ... impetuous judgments". ${ }^{94}$ Frank compared the "obstinacy of the police superintendent" to stubborn parents who rule their children with an "iron rod". Such a mode of policing, exercised under the "pretense of good order", could result only in the police earning the "hatred of the entire nation".95

The development of medical police was thus slower than Roberton, like Frank, would have liked. Indeed the successful deployment of medical police practice was almost inversely proportional to the extent to which those practices broke free of the idiom of police. One important consequence of this in England was that rather than police and persuasion becoming opposites, police was packaged in the language of persuasion. Thus Roberton argued that "regulation with ... [a] spirit of moderation" was the best means of convincing the "lower orders" that it was "not by the iron rod of oppression" that they were to be swayed, but by the "soft and persuasive advices of friendship". 96

\section{Variations on the Theme of Policing Health and Safety}

The growth of police in Europe was viewed with suspicion by many in England, and in this context the idiom of medical police itself became a political problem. Thus the first half of the nineteenth century saw a move away from talk of medical police and a proliferation of new labels or the resurrection of older ones. "Sanitary reform" became one of the most prevalent idiomatic nodes in the discourse of health enforcement. While intimately bound to theories about the health of the material environment, and hence the need for "sanitary engineering", the discourse also generated a new idiom of "sanitary police" (and even "sanitary sergeants"). Numerous other terms, such as "state medicine", "political medicine" and "public hygiene" increasingly appeared in the growing literature on science and health, cleanliness and Godliness. Analysis of the content of these publications, however, demonstrates that they did not constitute a radical break with earlier forms. In 1826, John Gordon Smith published his Principles of forensic medicine, a field that had also emerged in the eighteenth century and was sometimes classified as part of medical police. Smith

\footnotetext{
${ }^{93}$ Frank, op. cit., note 7 above, p. 11 .

94 Ibid., p. 222.

${ }^{95}$ Ibid., p. 222.
}

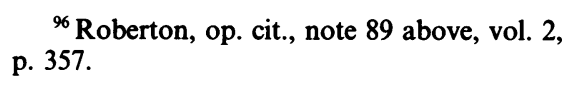




\section{Medical Police and the History of Public Health}

claimed that over 2,000 separate works in medical police, and almost 3,000 in forensic medicine had been published. ${ }^{97}$ For Smith, medical police and forensic medicine together constituted "medical jurisprudence", which Michael Ryan defined a decade later as "a science by which medicine and its collateral branches, are rendered subservient to the construction, elucidation, and administration of the laws for the preservation of public health" ${ }^{98}$ Ryan suggested that "medical jurisprudence" captured in the "most comprehensive manner, the application of the medical sciences to the purposes of law". ${ }^{99}$ Frank had insisted on a strict distinction between forensic medicine and medical police, but the two were grouped together as late as $1879 \mathrm{in}$, for instance, Aubrey Husband's Hand-book of forensic medicine and medical police. ${ }^{100}$

Husband separated the two branches within his text, dealing first with forensics and then with medical police, but the connections between them were numerous. Both depended for their practice on officers of police who went into the field to inspect events or situations with a view to the enforcement of the law. In both cases samples were collected and analysed in "police laboratories", and the same methods were used to detect the causes of illness, injury or death. For instance, in the case of poisoning, both medical police officers and forensic scientists were concerned with identifying and understanding various toxic substances and their indications in (primarily human) bodies, the former in the case of occupational illnesses or death, the latter in the case of deaths where persons may have been accidentally or deliberately poisoned. Both fields were concerned with identifying the causes of death or injury of citizens or subjects on behalf of the government, the connection between the two deriving from the earliest sense of general police, the remit of which was to protect the "public safety". As Black suggested in 1844, the "objects of public hygiene and medical police are not so closely allied and interwoven with those of the medical practitioner as several of those departments of forensic medicine". ${ }^{101}$

Through specialization and professionalization, medical police and forensics became increasingly distinct. The publication genealogy of Husband's work illustrates when this happened and how it related to the idiomatic shift from medical police to public health. The first edition was published in 1874 as an addendum to his textbook on forensics. The seventh edition was reworked and published as a "textbook of forensic medicine and public health", while in the eighth edition (1915) the two subjects were published in separate volumes. The section that began its life under the title of medical police in 1874 reached a twelfth edition in 1948, finally metamorphosing into a "textbook of public health".

\footnotetext{
${ }^{97}$ Smith, op. cit., note 55 above, p. xvii. Smith relied on Wildberg's Bibliotheca medicinae publicae for his figures. I have not been able to locate a copy of this publication.

${ }_{98}^{98}$ Michael Ryan, A manual of medical jurisprudence and state medicine, London, Sherwood, Gilbert, \& Piper, 1836, p. xiii. Ryan used "medical jurisprudence" and "legal medicine" interchangeably. A very welcome study of medical jurisprudence in America has recently been published, and makes important reference to
}

England: James C Mohr, Doctors and the law: medical jurisprudence in nineteenth-century America, New York, Oxford University Press, 1993.

${ }^{99}$ Ryan, ibid., p. xiii.

${ }^{100}$ Frank, op. cit., note 7 above, p. 11; $\mathrm{H}$ Aubrey Husband, The student's hand-book of forensic medicine and medical police, 3rd ed., Edinburgh, E \& S Livingstone, 1879.

${ }^{101}$ Black, op. cit., note 60 above, pt 19 , p. 275 . 


\section{Patrick E Carroll}

A similar genealogy can be mapped in regard to "medical jurisprudence". The term was used in the United States by John Beck (Brodhead) in the early 1830s. ${ }^{102}$ The first chapter of Beck's work was on "infanticide in its relations to medical jurisprudence and medical police". The chapter was based on his inaugural dissertation for the New York College of Physicians and Surgeons in 1817, and was later revised and enlarged as Elements of medical jurisprudence. Beck was a contributor to David Hosack's, Observations on febrile contagion, and on the means of improving the medical police of the city of New York (1820). ${ }^{103}$ In 1901, G H Giffen made the link to public health in his Students' manual of medical jurisprudence and public health. ${ }^{104}$ In 1903, Henry Chapman connected medical jurisprudence and toxicology with "mental hygiene", ${ }^{105}$ while William Robertson did the same for public health. ${ }^{106}$ Robertson's work, like Husband's, was eventually split in two, jurisprudence and toxicology in one volume and public health in another. Ryan's work on medical jurisprudence began its life in 1831 as an "analysis of a course of lectures on forensic medicine", expanding in the second edition of 1836 to encompass "state medicine". Forensic science went through a period of rapid development and differentiation in the nineteenth century. In many respects this gave rise, through its constitution of "poison" as a central epistemic object, to the new science of toxicology, a science which remains a crucial arm of all aspects of the government of life, especially in relation to forensics, environmental protection, occupational safety, the police of human and agricultural contacts with industrial chemicals and bio-hazards, and of course public health.

Ryan's Medical jurisprudence demonstrates the lack of an agreed upon demarcation for medical police, and highlights the range of terms available through which to designate the practice. According to Ryan, medical police, political medicine, state medicine, public hygiene, "police of health", and medical jurisprudence, together comprised "the acts of a legislature or government, and magistracy, for the conservation of public health", including (crucially) the regulation of medical practice. ${ }^{107}$ Ryan's work appeared in 1836, at a time when the proliferation of terms for describing medical police was causing confusion. The idiom of "State Medicine" emerged in the late-eighteenth to early-nineteenth centuries in Germany, and designated both medical police and forensics. In Britain and Ireland the term became synonymous

\footnotetext{
${ }^{102}$ John Beck, Researches in medicine and medical jurisprudence, 2nd ed., New York, E Bliss, 1835.

${ }^{103}$ David Hosack, Observations on febrile contagion, and on the means of improving the medical police of the city of New York, New York, E Bliss, 1820.

${ }^{104}$ G H Giffen, Students' manual of medical jurisprudence and public health, Edinburgh, Bryce, 1901. See also, Norman Chevers, A manual of medical jurisprudence for India, including an outline of a history of crime against the person in India, 3rd ed., Calcutta, Thacker, Spink, 1870.
}

\footnotetext{
${ }^{105}$ Henry Chapman, A manual of medical jurisprudence, insanity, and toxicology, 3rd ed., Philadelphia, W B Saunders, 1903.

${ }^{106}$ W G Aitchison Robertson, Manual of medical jurisprudence and toxicology, and public health, 3rd ed., London, A \& C Black, 1916.

${ }^{107}$ Ryan, op. cit., note 98 above, p. xiii. "Medical police" is still evoked when government intervenes in medical practice. George A Silver, 'Medical police in the twenty-first century', Postgraduate med. J., 1993, 69: 306-7.
} 


\section{Medical Police and the History of Public Health}

with medical police, of which forensics might or might not be a sub-category. ${ }^{108}$ Frank responded to the new term in the final volume of his work, noting that others had adopted "health police", "sanitary police", "public health police", and "even life security police". ${ }^{109} \mathrm{He}$ explained that his occasional use of the term "state medicine" was out of "deference" to those who preferred it, and not because it had any particular advantages over that of medical police. Regarding the absence of clarity in the meaning of police more generally, he noted that the jurists still lacked "a philosophical concept of the police which would reduce the variety of it to a common principle", so that its nature could be established and its limits defined. ${ }^{110}$

Ryan explained that "Judiciary" or "Judicial Medicine" related to the presentation of medical evidence in court. "Public Hygiene" (or just "Hygiene"), on the other hand, was the same as "Public Medicine"."11 This term became popular towards mid-century, and was defined by Ryan as the "laws, morals, and police of the people relating to the preservation of public health". ${ }^{112}$ "Political Medicine" could also be used interchangeably with medical police, state medicine, or public hygiene, though at other times it was limited to the theory or philosophy of medical police without reference to the design of administrative agencies. ${ }^{113}$ In each case, however, public health was the objective of medical police, political medicine, or state medicine, a condition of society to be achieved, rather than a practice in and of itself. And, like that of Roberton, Ryan's account of the objects of medical jurisprudence had the same scope and character as Frank's medical police. ${ }^{114}$

\footnotetext{
${ }^{108}$ For instance, Rumsey, op. cit., note 69 above. Idem, Essays on state medicine, London, John Churchill, 1856; Charles Moore, 'Remarks on state medicine', Dublin J. med. Sci., 1888, 85: 203-12; Anon., 'Essays on state medicine', Dublin q. J. med. Sci., 1856, 22: 146-50; William Stokes, William Stokes: his life and work 1804-1878, London, Fisher Unwin, 1898, esp. p. 131, pp. 170-3.

${ }^{109}$ Frank, op. cit., note 7 above, p. 285.

${ }^{110}$ Ibid., p. 287.

${ }^{111}$ Ryan, op. cit., note 98 above, p. xxi.

${ }^{112}$ Ibid., pp. xiv-xv.

${ }^{113}$ See, for instance, Cameron, op. cit., note 61 above. Cameron equated political medicine and state medicine, and defined the former as a science for the prevention of the causes of disease (p. 2). He defined hygiene as "the science which relates to the physical condition of man, and the means by which his health may be sustained, and his life prolonged to old age", p. 4. Henry Maunsell, Political medicine, Dublin, J Porter and Fannin, 1839; Anon., 'Dr Maunsell on political medicine', op. cit., note 55 above. John Gordon Smith treated political medicine as the equivalent of state medicine as understood in Germany, defining it as consisting of two branches, forensic medicine and medical police. Smith, op. cit., note 55 above, p. vi.
}

114 " 1 . Ages. - Characteristics and import of the several gradations in the period of human life, from the hour of birth to its natural decay, and final extinction; comprehending many circumstances relative to physical education, exercise, and other points of management. 2 . Marriage and population.-The proper period and subjects for the former, with the influence of these considerations on the welfare of descendants-fecundity, mortality, \&c. as questions of state importance. 3. General or national manners.-Their influence on health. 4. Air, food, and drink.-Importance of their purity and wholesomeness-including the medico-legal consideration of nuisances, adulterations, public cleanliness, ventilation, regulations for markets, slaughter-houses, burial-grounds, \&c. 5. Public buildings for numerous inmates.-As manufactories, barracks, prisons, hospitals, ships, \&c. as regards ventilation, warmth, economy, discipline, labour, \&c. 6. Topography.Comprehending climate, meteorology, soil, productions, \&c. of countries, and particular neighbourhoods. 7. Clothing and dwelling-places. 8. Employment and management of the poor, in order to preserve them from disease. 9.

Contagious, epidemic, and endemic diseases. Enumeration and history of the prevalent varieties; measures to be adopted to prevent their 


\section{Patrick E Carroll}

The idiom of "Public Hygiene" emerged in close connection with, rather than in opposition to, that of medical police. In 1844, James Black published a series of lectures on 'Public hygiene and medical police'. ${ }^{115}$ For Black, public hygiene was the objective, medical police the strategy for achieving that objective. Thus Black used the terms "public hygienist" and "medical police director" interchangeably, and defined medical police as a practice that investigated what was "injurious to public health", alleviating by "all scientific means, the sum of human misery or unhappiness". 116 A couple of years later, William Strange published an article in the London Medical Gazette, and also a small book, in which he made the case for a comprehensive system of national medical police. ${ }^{117}$ Strange argued that almost every position taken by Chadwick in his report on the Poor Law had been substantiated. He noted that the Health of Towns Bill, which sought to regulate "all those matters which concern the physical condition of our town population", contained clauses that were "proof" of the legislature's intention to establish "a more or less complete system of medical police". ${ }^{118}$ An anonymous article that appeared in 1855 made reference to a recently passed Act for "the better Local Management of the Metropolis". The article expressed the view that London had at last its own "system" of medical police through "which the whole of the modern Babylon may be placed under constant scientific sanitary supervision". ${ }^{119}$

Edwin Chadwick is widely remembered for his efforts to sanitize the working classes of England, and to use the power of government to force England to be healthy. ${ }^{120}$ Remembered less well is Henry Rumsey, ${ }^{121}$ whose work on "state medicine"

breaking out, or to arrest their progress. Here the important question of Quarantine will fall under consideration. 10. Dangers incident to certain situations.-As mines-during thunder-stormsand from a variety of accidents. Plans and institutions for resuscitating those apparently dead, from drowning, or other causes", Ryan, op. cit., note 98 above, pp. 477-8.

${ }^{115}$ Black, op. cit., note 60 above.

${ }^{116}$ Ibid., pt 19, p. 275 . Black presents medical police in terms of general climate; water and fuel; topographical climate and the atmosphere of towns; special "sources of insalubrity, noxiousness and discomfort that may arise from either want of attention to cleanliness or ventilation, or from the deleterious, or even unpleasantness of certain manufactures, chemical and other works, whose drainage or gaseous emanations if not positively injurious to health and property, at least come under the denomination of nuisances and occupational diseases." Ibid., pt 26, p. 391.

${ }^{117}$ William Strange, 'On the formation of a system of national medical police and public hygiene', Lond. Med. Gaz., 1846, 2: 452-7; idem, The health and sickness of town populations, considered with reference to proposed sanitary legislation, and to the establishment of a comprehensive system of medical police, and district dispensaries, with appendices and statistical tables, London, Parker, 1846. This is one of the most widely surviving English books on medical police, with copies in many US libraries and archives.

${ }^{118}$ Strange, 'On the formation of a system of national medical police', op. cit., note 117 above, pp. 452-3.

${ }^{119}$ Anon., 'The medical police of London', Journal of Public Health and Sanitary Review, 1855, 1: 324. The actual degree of systematicity of these schemes is questionable by today's standards, but the historical actors themselves seemed quite content to describe them in these terms. Indeed, even Frank's "complete system" of medical police might legitimately be viewed as a rather opportunistic grouping of objects and ideas with little theoretical integration or justification. It would be quite interesting, in this context, to conduct an historiographic investigation into the idiom of "system".

${ }^{120}$ Benjamin Ward, The health of nations: $a$ review of the works of Edwin Chadwick, with a biographical dissertation, 2 vols, London, Longmans, Green, 1887. Also the Report of the 


\section{Medical Police and the History of Public Health}

was perhaps the most comprehensive in mid-nineteenth-century Britain. ${ }^{122}$ Rumsey's Essays in state medicine (1856) presented a detailed plan for a comprehensive medical police for Britain, organized according to "state investigation", "sanitary regulations", and "administrative machinery". ${ }^{123}$ State investigation encompassed all the different types of information necessary for an effective statistical picture of the state of health, and for laying out the domains of investigation pertinent to medical policing. ${ }^{124}$ Sanitary regulations were distinguished as either preventative, which covered the police of nuisances and all aspects of human environments and activities, ${ }^{125}$ or palliative, which included everything related to the provision of health care by doctors and medical institutions, including the regulation of drugs and the appointment of medical officers of state. ${ }^{126}$ Administrative machinery dealt, on the one hand, with the training of sanitary police and the regulation of medical education generally, ${ }^{127}$ and on the other with the organization and police powers of medical councils and boards of health. ${ }^{128}$

Rumsey's plan of state medicine was quite innovative in its details, and was crafted to fit the specific political demands of the English context. In key conceptual ways, however, Rumsey's scheme for a system of state medicine was largely homologous - in terms of objects, mechanisms, techniques, purpose and rationale-with Frank's plan

Poor Law Commissioners, 1838, with its two supplementary reports: 'Report on the prevalence of certain physical causes of fever in the metropolis' (written by Neil Arnott and James Kay-Shuttleworth); 'Report on some of the physical causes of sickness and mortality to which the poor are exposed, and which are capable of removal by sanitary regulations' (written by Southwood Smith).

${ }^{121}$ See the still crucial contribution by MacLeod, op. cit., note 7 above.

${ }^{122}$ See, for instance, Rumsey, Essays, op. cit., note 108 above; idem, On state medicine, op. cit., note 69 above; idem, The educational aspects of state medicine, London, W J Goldbourne, 1868; idem, Essays and papers on some fallacies of statistics concerning life and death, health and disease, with suggestions towards an improved system of registration, London, Smith, Elder, 1875.

${ }^{123}$ Idem, Essays, op. cit., note 108 above.

${ }^{124}$ Rumsey classified the information according to three divisions. The first dealt with the extent of the population, mortality rates, fertility, rates of sickness and accidents, and the types and condition of dwellings. The second encompassed food and "animal life", physical geography, chemical analysis, and meteorological observations. "Legal" issues relative to jurisprudence, death-inquests, and government regulation of medical practitioners formed the third section.
${ }^{125}$ Preventative measures included the construction of towns and buildings, and the "purification of same viz. nuisances", water supply, drainage, sewerage, paving, and smoke pollution. Preventative measures also included physical education, the sale of food, medicines and poisons, the protection of workers and the public from the hazards of certain trades and occupations, modes of transportation, recreations and places of public resort and, of course, the handling of dead bodies.

${ }^{126}$ Special interventions were required during times of epidemic disease, such as house to house visitations, the use of quarantine power, the control of animal diseases, and government imposed vaccination campaigns.

${ }^{127}$ Including the registration and licensing of health professionals and veterinarians.

${ }^{128}$ Rumsey, 'Introductory-Outline of a Sanitary Code', in Essays, op. cit., note 108 above. See also, H W Rumsey, 'On certain departments of medico-sanitary police and medico-legal inquiry, in connexion with the scientific superintendence of mortuary registration', in Transactions of the National Association for the Promotion of Social Science, 1859 (hereafter NAPSS), London, John W Parker and Son, 1860, pp. 585-95. Rumsey concluded his talk by responding to those who held "that sanitary regulations do not come within the province of Government, and that systematic legislation for the public health is an improper 
of medical police, and he used the two terms, as well as that of "public medicine", interchangeably. Public health was still treated as the goal of medical police and state medicine rather than the practice itself. Rumsey was, however, acutely aware of English resistance to medical police, and went to some pains to reassure those who cried foul in the name of English liberty at the first sight of the word police. Apart, however, from the specificity of the way dissent in England was framed within a discourse of the "rights of free-born Englishmen", the concern about liberty and the proper limits of state power was not itself unique to England.

\section{Developments in Medical Policing in Nineteenth-Century England}

The question of the extent to which practice lived up to theory is always a difficult one. Advocates of medical police across the eighteenth and nineteenth centuries regularly complained that the legislature had not done enough, or that when laws were passed they lacked the administrative machinery to apply them or the police capacity to enforce them. Those who feared police, on the other hand, expressed the view that too much power had been granted to government and that the ancient constitution was being mortally wounded by the designs of police. When looked at narrowly, in relation to the politics of professional advantage and particular legislative episodes, the achievements appear rather ad hoc. Each extension of government power over bodies and their environment was forged in the mill of competing interests (government officials, doctors, engineers, water companies and so on), personal animosities (particularly in relation to Chadwick), ideological battles (English nationalist discourses), reactions to emergencies (epidemics and famine), and struggles between local and central authorities. When viewed broadly, however, the first significant century in the history of medical police (c. 1770-1870s) exhibits a politio-scientific coherence-a "governmentality" perhaps-that expressed a significant continuity across liberal and pre-liberal political discourses. Thus Rumsey could, in 1855, quote an English government agency in the idiom of medical police: "The Medical Council ... express their satisfaction at science having at length been recognized by the State as the ally of civil jurisprudence, and as the guide to a more enlightened code of Medical Police."129

Clearly the "idea" of medical police (and police generally) was not alien to English culture. It is equally evident that the discursive content of publications in the idiom of public health, medical police, state medicine and so on are not immediately distinguishable. A close analysis of the conceptual and epistemic content of medical police publications shows they are continuous with ideas more readily associated

interference with personal freedom of action", opining that the "opposition of this school appears to me to depend mainly upon their ignoring the distinction between PERSONAL HYGIENE, or the voluntary action of individuals in the preservation of their own health and that of families, and PUBLIC HYGIÉNE, or the legal action of society, by sanitary institutes, for the welfare and security of

\footnotetext{
the public." p. 594. The association created a "Special Committee on Registration and Sanitary Police", which drafted twelve resolutions on the subject. The resolutions were published the following year: NAPSS, 1860 , London, John W Parker, 1861, pp. xxvii-xxviii.

${ }^{129}$ Report of the Medical Council, 1855 , quoted in Rumsey, Essays, op. cit., note 108 above, dedication page.
} 


\section{Medical Police and the History of Public Health}

with the idiom of public health. The same is true for the practical solutions proposed. Government must intervene, inspect, make inquiries, and collect information. Law must be extended because regulation and enforcement are necessary. Certainly, in the case of England, the degree of centralization of authority was considerably less than, for instance, Austria. But it is less clear that central government in Austria achieved a more effective medical police than local government did in England. ${ }^{130}$ And by the end of the century the charge of political and financial excess could be as easily directed at local as at central government. ${ }^{131}$

It might be suggested that the publications discussed here constituted little more than fanciful theory, and that such ideas were never, in England at least, translated into practice. A survey, however, of the index of local Acts (Class II-Improvements) ${ }^{132}$ passed by the parliament of the United Kingdom between 1801 and 1865 suggests that the theories, objects, and strategies of medical police were indeed put into (albeit decentralized) practice. Hundreds of Acts passed during this period established a genuine police of health across England and its Kingdom. ${ }^{133}$ It might be suggested that these acts, even when taken together, constituted nothing approaching a "system", but an examination of the legislation illustrates that the law in nineteenthcentury England increasingly expressed the principle of policing the public's health and safety. Framed in the language of "improvement", reference was regularly made to "police", and legislation extended government authority in precisely the manner

\footnotetext{
${ }^{130}$ It is arguable that the United States, despite its dispersed structures of government, possesses as high a level of medical policing as any state anywhere in the world.

${ }^{131}$ Sally Sheard, 'Profit is a dirty word: the development of public baths and wash-houses in Britain 1847-1915', Soc. Hist. Med., 2000, 13: 63-86, p. 84.

${ }^{132}$ Class II-Improvements covered all government actions relative to paving, lighting (other than by a private company), watching, policing, sewerage, public buildings, municipal regulations and "Two Pennies Scots Duties".

${ }^{133}$ For instance: 6 Geo. 4. c. 5, lighting, cleansing, policing, Ardwick. 7 \& 8 Geo. 4. c. 77, lighting, watching, policing Ashton-under-Lyne. 25 \& 26 Vict. c. 32 , enabling local board of health to construct and maintain improved waterworks, and conferring powers on park keepers and constables in Barnsley. 41 Geo. 3. c. 126 , paving, lighting, and establishing police for Bathwick. 3 \& 4 Will. 4. c. 68 , paving, lighting, policing Birkenhead. $41 \mathrm{Geo}$. 3. c. 39, cleansing, lighting, policing Birmingham. 2 \& 3 Vict. c. 95 , improving police in Bolton. 6 Geo. 4 c. 121, lighting, watching and policing Burslem. $59 \mathrm{Geo}$. 3 c. 3 , police, paving, and cleansing in Calton. 13 \& 14 Vict. c. 37 , improving and policing Cambridge. 43 Geo. 3 c. 47 , watching, lighting, cleansing, policing Chester. 59 Geo. 3. c. 118, paving, cleansing, lighting Harwich. 24 \& 25 Vict.
}

c. 176, maintaining an efficient system of police in Harwick. 9 \& 10 Vict. c. 31, lighting, cleansing and establishing police in Helensburg. $21 \& 22$ Vict. c. 120, establishing more efficient police regulations for Hove. 1 Geo. 4 c. 43 , maintaining an efficient police and removing and preventing nuisances and annoyances for Huddersfield. 5 Geo. 4 c. 95, lighting, watching, improving and policing Hulme. 55 Geo. 3. c. 42, establishing a police and nightly watch for Leeds. $9 \mathrm{Geo}$. 4. c. 27, paving and police of Lincoln. 7 Geo. 4. 57, improving streets, preventing nuisances, regulating weights and measures, and establishing a fire police for Liverpool. $4 \& 5$ Will. 4. c. 77, constabulary of London. $7 \& 8$ Vict. c. 40 , good government and police regulation of Borough of Manchester. 7 Geo. 4. c. 117, paving, watching, lighting, and policing Oldham. 46 Geo. 3. c. 116, paving, improving streets, erecting a bridwell or workhouse, and regulating the markets and police of Paisley. 5 Geo. 4. c. 22, better paving and policing of Plymouth. 9 \& 10 Vict. c. 299, government and police of Rothsay. 6 Geo. 4. c. 131 , lighting and policing Sneyd Green. 2 \& 3 Vict. c. 44, lighting and policing Staffordshire Potteries. 9 Geo. 4. c. 26, paving and policing Stalybridge. 7 Geo. 4. c. 118, lighting, cleansing, and policing Stockport. 43 Geo. 3. c. 59, paving, lighting, watching, and establishment of police for Worthing. 6 Geo. 4. c. 123, paving, lighting, watching and policing York. 


\section{Patrick E Carroll}

recommended by those who in England wrote in the idiom of medical police. The link between the idiom of improvement and police in the Acts relating specifically to England maps onto that which was expressed in the earliest articulations of police, famously in respect to Scotland. And the legislation was given an increasing degree of national coherence, beginning in the late 1840s with six Acts for the "consolidation of local acts" relative to commissioners, police, improvement, sanitation, public health, and local government. ${ }^{134}$

It seems important, in this respect, that centralization of police authority should not be viewed as the sole or even master-criterion for empirically ascertaining the extent of medical police practice. ${ }^{135}$ The relationship between police and centralization was not an essential and dependent one. Local and decentralized police, permission for which was granted in England by central authority, was an effective way to secure a policed state. ${ }^{136}$ Chadwick argued in his 1829 essay on 'Preventative police' that the English system of "disjointed bodies of men" under heterogeneous regulations would be better if replaced by "one well-organized body of men". ${ }^{137}$ While this did not happen in England an effective police was none the less established. Chadwick also suggested, in his Constabulary Report of 1839 , that the general police should operate as the nation's "fire police". He lauded the fire police of London, which was a branch of the regular metropolitan force. His scheme was not, again, adopted. But the independent and decentralized "Fire Brigade system" eventually adopted across England and the Kingdom was none the less endowed with considerable police power to investigate, regulate and prosecute. ${ }^{138}$

Considering the law created for the police of commerce, particularly commerce in matter ingested by human bodies and which was believed to be a source of disease if "dirty" or "rotten", the image is more one of medical police than the commerce

$13410 \& 11$ Vict. c. 16 , consolidating in one Act certain provisions usually contained in Acts with respect to the constitution and regulation of bodies of Commissioners appointed for carrying on undertakings of a public nature. $10 \& 11$ Vict. c. 34 , consolidating in one Act certain provisions usually contained in Acts for paving, draining, cleansing, lighting, and improving towns. 10 \& 11 Vict. c. 89 , consolidating in one Act certain provisions usually contained in Acts for regulating the police of towns. $10 \& 11$ Vict. c. 63, an Act for the promotion of public health. 10 \& 11 Vict. c. 95, an Act to make better provision for the administration of the laws relating to the public health. $10 \& 11$ Vict. c. 98 , an Act to amend the public health Act of 1848, and to make further provision for the local government of towns and populous districts.

${ }^{135}$ MacLeod shows how, despite the lack of central command over English "state medicine" in the late nineteenth century, it was still "one of the most effective systems in the world." op. cit., note 7 above, p. 227. Also, Roy MacLeod (ed.), Government and expertise, Cambridge University Press, 1988.

\footnotetext{
${ }^{136}$ Sixty-nine separate "general Acts" relative to police were passed by parliament between 1801 and 1865 . Though most were amendments to previous Acts, more than one piece of police legislation per year does not support the idea that police was un-English. See for instance: 3 \& 4 Vict. c. 50, police of canals and inland navigation. 2 \& 3 Vict. c. 93, authorizing Justices of the Peace to establish County and District Constabularies. 23 \& 24 Vict. c. 135, establishing dockyard police. 10 Geo. 4. c. 44 , improving police of London. $20 \& 21$ Vict. c. 64 , funding police stations. 2 \& 3 Vict. c. $87,88,95$, improving police in Manchester, Birmingham and Bolton. 5 \& 6 Vict. c. 109, appointment and payment of parish constables. $1 \& 2$ Vict. c. 80 , policing public works projects. 2 \& 3 Vict. c. 93 , establishing rural police. $10 \& 11$ Vict. c. 89 , consolidating in one Act certain provisions usually contained in Acts for regulating the police of towns in England and Ireland.

${ }^{137}$ Quoted in Ward, op. cit., note 120 above, p. 389 .

${ }^{138}$ Ibid., pp. 418-30.
} 


\section{Medical Police and the History of Public Health}

police imagined by Colquhoun. While manufacture continued throughout the nineteenth century to injure, sicken and kill workers, the police of "markets", if still only in limited cases, had been firmly and irreversibly established. And Sheard has shown that there is another important sense in which the relationship between capitalism, government and health needs to be understood. As sanitation became a new secular religion, business opportunities arose that were eagerly pursued. Public baths became a site of struggle where "profit" was sometimes construed as a "dirty word". ${ }^{139}$ Engineers specializing in sanitation were quick to recognize that there was profit in health, some advertising in search of partnerships with "sanitary capitalists". ${ }^{140}$ Sheard explains how concerns for economy opened up the provision of services like public baths and wash-houses to the suggestion that they should be "self-sufficient". ${ }^{141}$

English medical police continued to be extended in practice throughout the nineteenth century even if talk of police was somewhat muted compared with other countries. Since disease and premature death were concentrated most strongly amongst the poor (the "dangerous classes"), it is not surprising that English measures (as in Ireland) were especially directed at that section of the population. ${ }^{142}$ Yet after the creation of the Poor Law Commission in 1834 (an elaborate deployment of what Hanway understood as police), the scope was widened. Amongst the most important early developments were the Liverpool Sanatory [sic] Act (1846), the Nuisances Act (1846), Baths and Washhouses Act (1846), Towns Improvement Act (1847), ${ }^{143}$ Public Health Act (1848) and the Lodging Houses Acts (1851). ${ }^{144}$ Important also, and leading up to the more comprehensive local government and public health legislation of the 1870s, was the appointment of Medical Officers of Health in Liverpool (1846), London (1848), Leeds (1866), Manchester (1868), Birmingham (1872) and Newcastle (1873). No less important was the police of medical practice and education initiated by the creation of the General Council of Medical Education and Registration. ${ }^{145}$

\footnotetext{
${ }^{139}$ Sheard, op. cit., note 131 above. There was in fact a long tradition of such, the commerce in night soil collection, and street building and lighting going back to the eighteenth century at least. See Roy Porter, 'Cleaning up the great wen: public health in eighteenth-century London', in W F Bynum and Roy Porter (eds), Living and dying in London, Med. Hist., Supplement, No. 11, London, Wellcome Institute for the History of Medicine, 1991, pp. 61-75.

${ }^{140}$ Consider, for instance, the following advertisement: “To SANITARY CAPITALISTS, ENGINEERS, ARCHITECTS, Surveyors, Builders, and Firegrate Manufacturers, \&c. THE LATEST AND BEST THING OUT! - WANTED, ONE Or TWO of the above kind of practical and energetic GENTLEMEN, to form a select Company for the more scientific and cheap CONSTRUCTION, WARMING (including COOKING), and complete VENTILATION of the future DWELLINGS of all classes." The sanitary review: a monthly record of sanitary science, and devoted to all subjects which affect the health and welfare of the
}

people, London, Model Houses Association, 1875 , p. 1.

${ }^{141}$ While some wash-houses in England were permitted to charge fees as a means to offset the burden of rates, Scottish municipal enterprises "were in theory not allowed to make profits". Sheard, op. cit., note 131 above, p. 79.

${ }^{142}$ The Elizabethan Poor Law was an exceptionally early example of the police of the poor.

${ }^{143}$ Citing period complaints about the inadequacy of sanitary engineering projects, Hamlin suggests that there was a "difference between typical urban improvement and true public health". Hamlin, op. cit., note 3 above, p. 273.

${ }^{144}$ The conflict between the Poor Law centred model and the independent public health model is well known, and continued throughout the century.

${ }^{145} 21$ \& 22 Vict. c. 90, s3 (UK). See Margaret Stacey, Regulating British medicine: the General Medical Council, Chichester, John Wiley, 1992; Russell G Smith, 'The development of ethical 


\section{Patrick E Carroll}

These measures were sometimes compelled by emergencies or were severely weakened as they moved through the legislative process. The Liverpool Act, for instance, was prompted by the sudden inflow of Irish famine victims. The General Board of Health, established by the Public Health Act (1848), was temporary in form and short-lived in practice. Other measures were largely local and often only permissive. These qualifications need not, however, be read as failure. Permissiveness was granted more to the local government than the subjects of that government, and emergency actions can be viewed less as signs of failure than as typical of how medical police developed, and indeed how "emergencies" were constructed as crucial objects of all police. ${ }^{146}$ Regardless, however, of how one might construe the systematicity of these developments, there can be little doubt that they furthered the practice of policing public health and safety in England.

Comprehensive legislation passed for England in the 1870s was modelled on that deployed in Ireland in $1851 .{ }^{147}$ In addition to the central inspectorate of the Local Government Board, and the some 4,000 Poor Law medical officers already in existence, legislation led to the employment of over 800 police officers of health in England by 1876 . By the end of the century almost 1,800 annual inspectors' reports were being filed with the Local Government Board. Much has been made of the limitations of these offices, and indeed there were many. None the less, they constituted important developments of English medical police practice that were cut not from whole cloth, but from a long developing discourse concerning the designs of police and its necessity for arresting disease and securing health. Robert Druitt, a medical police officer who later became president of the inspectors' professional association, apparently convinced at least some governors that police was not un-English. Druitt suggested that "great truths" often lay at the roots of words, and that the word police illustrated this: "Taken in its true and original meaning, it signifies the art or science of the government of cities ... In this sense, the science of police becomes a liberal and ennobling study." 148

\section{Conclusion}

Eighteenth- and nineteenth-century categories for describing housing regulation, nuisance abatement, the regulation of manufactures and so on, were not fixed. This discursive instability is detectable in idiomatic competition over how best to describe what is now called public health, and indicates that the definition of health practices and the constitution of a respective body of knowledge was still formative well into the late nineteenth century. A complete story would extend this analysis into the twentieth century, tracking the rise and fall of the idiom of "state medicine". But enough has been said to demonstrate why the idea that medical police and public

guidance for medical practitioners by the General Medical Council', Med. Hist., 1993, 37: 56-67.

${ }^{146}$ The history of the "emergency services" is of great interest in this respect.

${ }^{147}$ Cassell, op. cit., note 68 above, pp. 161-2, and ch. 7.

\footnotetext{
${ }^{148}$ Robert Druitt, 'Short notes on some details of sanitary police', Journal of Public Health and Sanitary Review, 1855, 1 (1): pp. 15-16.
} 


\section{Medical Police and the History of Public Health}

health were two distinct groups of ideas and practices-one following the other in historical time, and each inversely related to the other by virtue of an essential link to particular nation-states or political economic theories-offers an understanding that the record does not readily sustain. Medical police, state medicine, public medicine, medical jurisprudence, public hygiene, sanitarianism, and political medicine, do not readily correspond with distinct and coherent paradigms (political or scientific) that appeared and disappeared at different times and in different European countries.

Reference to medical police evoked associations with police more generally and these associations raised suspicions within the political nation (franchised) and among the people, working as well as propertied. The controversial development of new disciplined (for some observers, militaristic) police forces raised the stakes of speaking in the idiom of police. English nationalist discourses represented police as the antithesis of English free-born liberty precisely by associating it with "continental absolutism" and by declaring it "foreign" to English political mores. ${ }^{149}$ As Chadwick pushed the first General Board of Health towards greater centralization, the editors at The Times famously expressed their view that they would rather take their chances with cholera than be bullied into health by government (characterized and demonized in the person of Chadwick).

Advocates of greater government surveillance, investigation, information gathering, intervention and enforcement in the name of national health were aware of the opposition sparked by talk of medical police, and indeed police in general. "State medicine" was perhaps a little more palatable (and survived well into the twentieth century), but, as Rumsey noted, the term was often construed as "dark" ${ }^{150}$ It was also open to ridicule as dissenters suggested that one might as well have a "state chemistry" or "state physics". Talk of medical jurisprudence survived into the twentieth century, particularly in the United States, but was connected more directly to court proceedings than medicine or public health. Talk of judicial and judiciary medicine faded as forensic science and medical jurisprudence expanded. Forensic medicine, as is well known, became a premier police science, but was eventually detached from the discourse of medical police. The idiom of "public health", in partnership with "(public) hygiene" and "preventative medicine", was the most benign. In the end it won the day and became the master-designation for all the practices first articulated as constituting the domain of medical police.

As Sigerist suggested, persuasion and education did not stand in opposition to police. Both were configured in new ways. The idiomatic shift from medical police to public health is not an unproblematic barometer of what was happening at the level of practice. The content of publications in the idioms of public health, state medicine, medical jurisprudence and medical police, indicates an important degree of continuity in the philosophy of the government of health across the vicissitudes of political ideology, the boundaries of nation-states, and even shifts in medical,

\footnotetext{
${ }^{149}$ Carroll-Burke, op. cit., note 40 above, pp. 179-236.

${ }^{150}$ On the struggles of state medicine in relation to Treasury Office priorities, see Roy
}

MacLeod, 'The frustration of state medicine, 1880-1899', Med. Hist., 1967, 11: 15-40. 
chemical, and biological theory. A complete genealogy of the dis/connections between the different idioms would be of great value. It is clear that between the idioms of medical police and public health, numerous terms designating the enforcement of health appear and disappear. Less clear is whether the enforcement of health through the power of police ever faced substantial reversal. The idea that the history of public health in England constitutes an "opposite" model to that of the rest of Europe, particularly Germany, should not be assumed. While the differences are important and should not be minimized, over-emphasis upon them obscures the similarities. As Paul Weindling has shown, German public health remained more decentralized in practice than has generally been assumed. ${ }^{151}$ And, as in England, German police was meant to be fair in design and execution, von Justi explaining that

one must especially underscore that a kind and mild government, a reasonable freedom allowed to citizens to engage in innocent actions irrelevant [to the good of civil society], and complete freedom of conscience must be made room for in a city, if one wants to encourage its expansion and growth. One can have little hope of growth for a city in which everybody does not enjoy complete civil freedom and freedom of conscience. ${ }^{152}$

In this respect as in others, the English case is less the singular exception that stands in opposition to the rest of Europe, than one particular example of the development of modern forms of the government of health. However one chooses to speak of these government forms, in every case the use of law and police to inspect, regulate, and enforce health and safety remained central, in England as elsewhere, both to the culture and to the practice of public health. Indeed, this continued to be the case with the rise of bacteriology and the "New Public Health", and with the emergence of a new idiom of "social medicine" in twentieth-century England.

Perhaps the most infamous example of bacteriology, the New Public Health and medical police coming together is the case of "Typhoid Mary". The New York medical police officer who arrested Mary (in the company of two regular police officers) later reflected on how there was "little that a Board of Health cannot do in the way of interfering with personal and property rights for the protection of public health". ${ }^{153}$ It would be wrong, however, to think of Mary's case as constituting the "ideal type" of medical police in action. Medical police was not simply about a

\footnotetext{
${ }^{151}$ Weindling, op. cit., note 3 above. Even in France, "whose name is virtually synonymous with centralization", the actual history has been shown to be more like England than long believed. Ramsey, op. cit., note 8 above, p. 45.

152 J H G von Justi, Die Grundfeste zu der Macht und Glückseeligkeiten der Staaten, 2 vols, Königsberg, J H Hartungs Erben, 1760, vol. 1, par. 387 , pp. $330-1$, quoted in Hull, op. cit., note 4 above, p. 170 .

${ }^{153}$ Quoted in J Andrew Mendelsohn, "Typhoid Mary" strikes again: the social and the scientific in the making of modern public health', Isis, 1995, 86: 268-77. Though his discussion of "the social" and "the scientific" resurrects
}

(without new insight) the internal/external distinction in the historiography of science, Mendelsohn recognizes that the emphasis on personal cleanliness by advocates of bacteriology did not signal a decline in medical police practice. See also, Judith Walzer Leavitt, "“Typhoid Mary" strikes back: bacteriological theory and practice in early twentieth-century public health', Isis, 1992, 83: 608-29; idem, Typhoid Mary: captive to the public's health, Boston, Beacon Press, 1996; Nancy J Tomes, 'American attitudes towards the germ theory of disease: Phyllis Allen Richmond revisted', J. Hist. Med. Allied Sci., 1997, 52: 17-50. 


\section{Medical Police and the History of Public Health}

form of governmentality built upon medical and state domination. Like police generally, the facts of the matter are too complex to be adequately captured by the singular image of the repressive hypothesis.

In twentieth-century England the idiom of "social medicine" brought medical police into a new relationship with "social justice". ${ }^{154}$ Despite important differences, the history of social medicine is continuous with a longer history of political philosophy, police, and the activism for health as a "right". In this context the "National Health Service" (1946) became a powerful department of British government that brought medicine and police into a closer relationship with justice and "welfare". ${ }^{155}$ Though won in struggle by the voice and power of labour, the idea remained tied to a genealogy of practices with a much longer history. Though ideologies varied enormously over this history, this only makes the similarities more interesting, similarities that lie in the mundane details of the everyday practices and knowledges associated with the enforcement of health, safety and security.

I have suggested that while it is necessary to comprehend the complexity of difference in the history of medical police and public health, it is equally valuable to comprehend the similarities. When the history of health and safety-public health - and the history of safety and security - police - are treated separately, each becomes difficult to square with the empirical record. Police remained central to public health because health and safety continued to figure in the more general idea of security. It is thus security and not crime that best captures in a single word the purpose of the institution of police.

Framed in terms of national and localist historiographies, the differences between Europe and the US, Britain and the continent, England and the other nations of the UK, or the districts and localities of England, are well documented. The same is true of chronological differences. Within an historiography of "reflection" each "age" is shown to have its own peculiar forms of "public health". Acknowledging these differences does not, however, mean that all talk of similarity and continuity is misplaced. The historiographical point is that particulars are not a substitute for general observations any more than generalizations are a substitute for sensitivity to difference. I have tried to demonstrate in this paper that the difference between public health and medical police does not rise to the level of an opposition, and that the difference between England and other western states does not rise to the level of exceptionalism.

It may appear contradictory to suggest as I do that the development of liberal political economy was accompanied by an increase, relative to the era of cameralism and mercantilism, in government intervention for the enforcement of health, safety and security. Yet as Karl Polanyi demonstrated, the discourse of English political

\footnotetext{
${ }^{154}$ John Ryle, who became the first professor of social medicine in Britain in 1942, led the movement to create a "medicine of society for society". Dorothy Porter, 'Social medicine and the new society: medicine and scientific humanism in mid-twentieth century Britain', J. Hist. Sociol., 1996, 9 (2): 168-87.
} 


\section{Patrick E Carroll}

economy was crucially ideological, because there was "nothing natural about laissez faire". ${ }^{156}$ On the contrary, the "road to the free market was opened and kept open by an enormous increase in continuous, centrally organized and controlled interventionism". ${ }^{157}$ Polanyi's insight is readily applicable to the history of the relationship between police and public health. Though the liberal discourse of nonintervention and self-regulation with respect to markets was extended into the domain of public health, the latter was in fact secured (to the extent that it was) by the expansion of the police power of government. ${ }^{158}$ This is not an argument for "sanitary teleology", or a suggestion that the state had to grow precisely as it did. ${ }^{159}$ It is, however, a critique of (neo) liberal ideology. Just as "real market economies need the [sovereign government] to play an active role in managing markets", 160 so real public health systems require police power if they are to secure health and safety. Thus it has always been less a choice between medical police and public health, than a question of how the police of health and safety might be constituted in societies that aspire to freedom and social justice.

\footnotetext{
${ }^{156}$ Karl Polanyi, The great transformation: the political and economic origins of our time, foreword by Joseph E Stiglitz, introduction by Fred Block, Boston, Beacon Press, 2001 [1944], p. 145.

${ }^{157}$ Ibid., p. 146.
}

${ }^{158} \mathrm{~T}$ Johnson, G Larkin, and M Saks, Health professions and the state in Europe, New York, Routledge, 1995.

${ }^{159}$ Hamlin, op. cit., note 3 above, p. 273.

${ }^{160}$ Fred Block, introduction, Polanyi, op. cit., note 156 above, pp. xviii-xxxviii, p. xxvi. 